\title{
State International Fuel Tax Agreement (IFTA) Data Reporting Procedures
}

\section{April 2003}

\author{
R. L. Schmoyer \\ and \\ R. G. Boundy
}




\section{DOCUMENT AVAILABILITY}

Reports produced after January 1, 1996, are generally available free via the U.S. Department of Energy (DOE) Information Bridge:

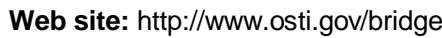

Reports produced before January 1, 1996, may be purchased by members of the public from the following source:

National Technical Information Service

5285 Port Royal Road

Springfield, VA 22161

Telephone: 703-605-6000 (1-800-553-6847)

TDD: 703-487-4639

Fax: 703-605-6900

E-mail: info@ntis.fedworld.gov

Web site: http://www.ntis.gov/support/ordernowabout.htm

Reports are available to DOE employees, DOE contractors, Energy Technology Data Exchange (ETDE) representatives, and International Nuclear Information System (INIS) representatives from the following source:

Office of Scientific and Technical Information

P.O. Box 62

Oak Ridge, TN 37831

Telephone: $865-576-8401$

Fax: 865-576-5728

E-mail: reports@adonis.osti.gov

Web site: http://www.osti.gov/contact.html

This report was prepared as an account of work sponsored by an agency of the United States Government. Neither the United States government nor any agency thereof, nor any of their employees, makes any warranty, express or implied, or assumes any legal liability or responsibility for the accuracy, completeness, or usefulness of any information, apparatus, product, or process disclosed, or represents that its use would not infringe privately owned rights. Reference herein to any specific commercial product, process, or service by trade name, trademark, manufacturer, or otherwise, does not necessarily constitute or imply its endorsement, recommendation, or favoring by the United States Government or any agency thereof. The views and opinions of authors expressed herein do not necessarily state or reflect those of the United States Government or any agency thereof. 


\title{
State International Fuel Tax Agreement (IFTA) Data Reporting Procedures
}

\author{
R. L. Schmoyer \\ and \\ R. G. Boundy \\ April 2003 \\ Prepared for the \\ Office of Highway Policy Information \\ Federal Highway Administration \\ U.S. Department of Transportation \\ Washington, D.C. 20590
}

Prepared by

OAK RIDGE NATIONAL LABORATORY

P.O. Box 2008

Oak Ridge, Tennessee 37831-6285

managed by

UT-Battelle, LLC

for the

U.S. DEPARTMENT OF ENERGY under contract DE-AC05-00OR22725 



\section{Contents}

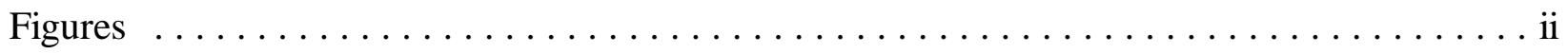

Acknowledgment $\ldots \ldots \ldots \ldots \ldots \ldots \ldots \ldots \ldots \ldots \ldots \ldots \ldots \ldots \ldots \ldots \ldots \ldots$ iii

Executive Summary $\ldots \ldots \ldots \ldots \ldots \ldots \ldots \ldots \ldots \ldots \ldots \ldots \ldots$ iv

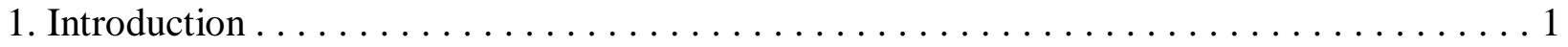

2. IFTA Data Reporting-General Background $\ldots \ldots \ldots \ldots \ldots \ldots \ldots \ldots \ldots$

3. How Each State Collects IFTA Revenues $\ldots \ldots \ldots \ldots \ldots \ldots \ldots \ldots \ldots \ldots \ldots$

4. How Each State Separates out Revenues Not Related to Gallons

of Motor-fuel and Direct Motor-fuel Gallon Taxes . . . . . . . . . . . . . 16

5. How Each State Calculates Net IFTA Gallons $\ldots \ldots \ldots \ldots \ldots \ldots \ldots \ldots \ldots$

6. Other Difficulties in Processing and Reporting IFTA Data $\ldots \ldots \ldots \ldots \ldots \ldots \ldots \ldots$

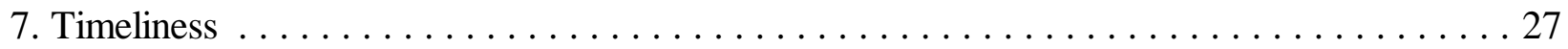

8. Alternatives for IFTA Calculations if the Complete IFTA Data Are Not Available . . . . . 30

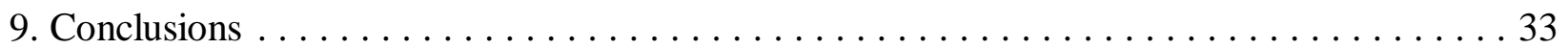

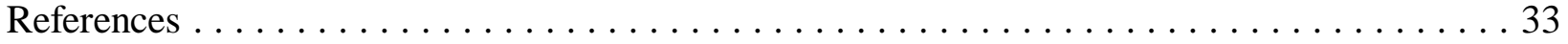

Appendix A. IFTA Survey (January 2002) Questionnaire . . . . . . . . . . . . . . 35

Appendix B. IFTA Survey (January 2002) Instructions for Questionnaire . . . . . . . . . . 38 


\section{Figures}

ES-1. States responding to the FHWA's IFTA Survey, conducted January-April 2002 . . . . . . v

1. Average annual apportionments under ISTEA and TEA- $21 \ldots \ldots \ldots \ldots \ldots \ldots \ldots$

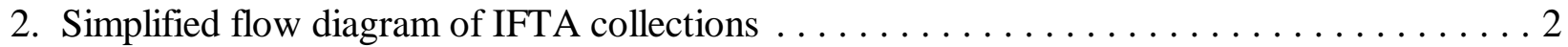

3. The Flow of IFTA Fuel Consumption Information to FHWA-A Generalization (Not Exact

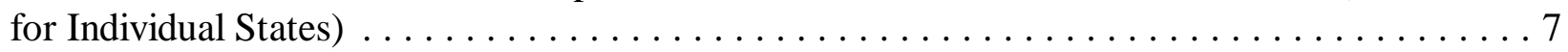

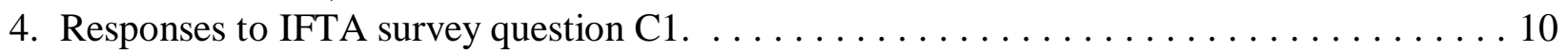

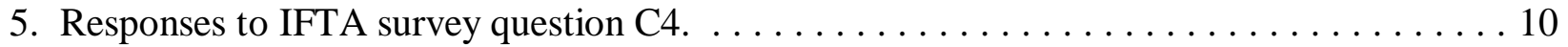

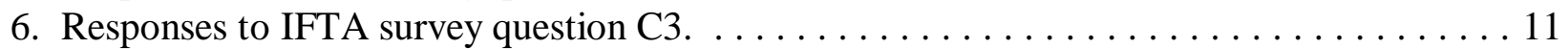

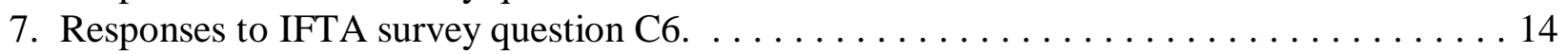

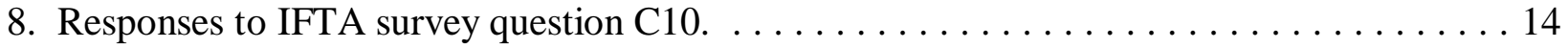

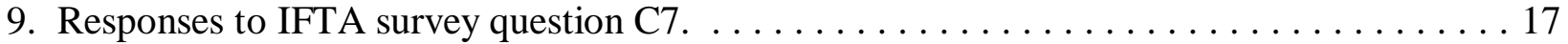

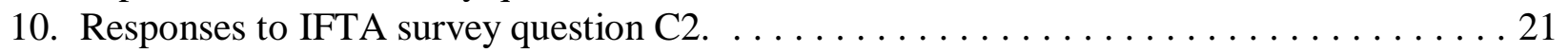

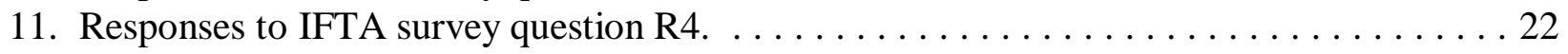

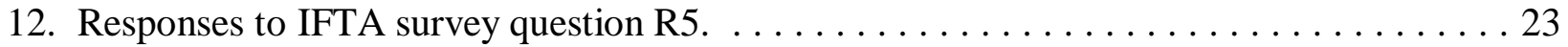

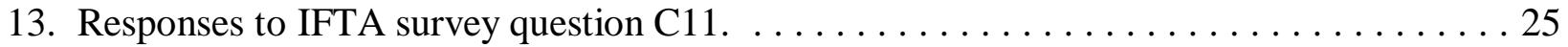

14a. Responses to whether IFTA data is used for the $551 \mathrm{M}$ forms (the first part of IFTA survey

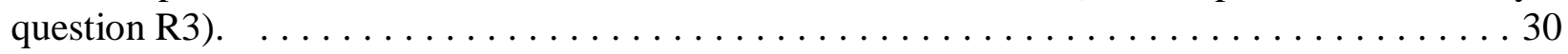
14b. Responses to whether IFTA data is used for the 556 forms (the second part of IFTA survey

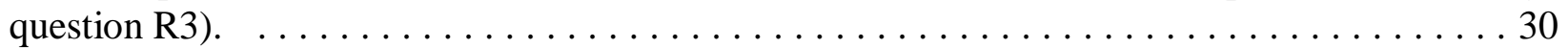




\section{Acknowledgment}

The authors would like to thank Ralph Erickson of FHWA for invaluable guidance in developing the statistical survey of State IFTA collections and reporting personnel, which is the foundation of this report. 


\section{Executive Summary}

This report documents a review of State practices of reporting International Fuel Tax Agreement (IFTA) data to the U.S. Federal Highway Administration (FHWA). The purpose of the review is described in a notice published in the Federal Register (Vol. 65, No. 160, August 17, 2000, 50269-50272). The purpose is "to increase the understanding of States on the importance of reporting adjusted IFTA data to the FHWA," and "to develop additional guidance on IFTA reporting." The purpose is not to critique IFTA or any State. The review includes a survey of the forty eight IFTA member States, which was conducted January-April 2002. The States' responses to the survey are discussed in this report.

The organization of the report follows further discussion in the Federal Register notice. Section 2 of the report is a general overview of IFTA. Section 3 describes in more detail how each State collects IFTA revenues. Section 4 is about how States separate out revenues not related to gallons of motor-fuel and direct motor-fuel gallon taxes. Section 5 describes how States calculate net IFTA gallons and the time delay in the processing. Section 6 is about difficulties in processing and reporting IFTA data. Timeliness is discussed further in Section 7, and alternatives for IFTA calculations if complete IFTA data are not available are discussed in Section 8. The IFTA survey questionnaire and instructions are in Appendices A and B.

The survey responses of the States and the review of the IFTA system suggest that IFTA collections and data reporting are for the most part working well. Possible exceptions include (1) using off-road fuel use in IFTA mileage-per-gallon (mpg) estimates, (2) inconsistencies among States in definitions of taxable mileage or taxable fuel and consequential reporting differences, and (3) possible misinterpretations of "net taxable gallons."

The problem with using off-road fuel use in IFTA mpg estimates is that it tends to inflate taxable volume consumption estimates, because off-road per-gallon mileage is generally lower than onroad mileage. The problem with inconsistent definitions of taxable mileage or fuel is that IFTA taxable gallons for one State can include fuel that if used in another State would not be included. In Idaho, for example, fuel usage on privately maintained roads on private property is not taxable; in Connecticut all miles are taxable.

The problem with the interpretation of "net taxable gallons" is that in the language of FHWA, for example on the FHWA 551M form, "net taxable gallons" refers to the difference between taxable gallons used and taxable gallons purchased. In the language of IFTA, on the other hand, "net taxable gallons" refers to a balance of gallons on which taxes are due. Consequently the IFTA net taxable gallons differ from the IFTA adjustment sought by FHWA for the 551M forms. The difference is equal to the volume purchased tax-refunded less the volume purchased tax-due.

Several other possible exceptions to the smooth operation of IFTA collections and data reporting are also discussed in the report. Although none of the State personnel responding to the survey indicated that there is accounting or auditing evidence that motor carriers may be misreporting mileages to try take advantage of State-to-State differences in fuel tax rates, some of the State personnel said they believe this to be the case. Mileages misreported this way would tend to incorrectly reduce the IFTA mileages and volumes reported for States with higher fuel tax rates.

Other possible exceptions to smooth operation include mileage deductions for travel on the Massachusetts Turnpike (which, under Massachusetts General Law, is technically non-highway 
use); possible misinterpretations of what is considered "IFTA" on 551M reports; the dependency of the entire system on the accuracy of trucker reports; fuel tax exemptions, in certain States, for IFTA-qualified buses or two-axle trucks; and commingling, in the accounting, of direct fuel tax revenue with revenue (e.g., penalties and interest) not directly proportional to volumes consumed.

Responses to the IFTA survey suggest that late reporting is not seen by the States as a serious problem in IFTA data reporting to FHWA. Nevertheless, delay could still be a problem from FHWA's perspective. Furthermore reporting delays, if encountered, might be remedied fairly easily with interim estimates computed from such data sources as time series of previous and ontime current data from States that are similar to the State whose data is delayed. Interim estimates are discussed in Section 8 of the report.

Although the IFTA collections and FHWA reporting systems are not perfect, the general tone of the responses to the survey is positive. IFTA is a vast improvement over earlier fuel tax collection systems in which motor carriers had to report separately to each jurisdiction they operated in. In general the survey respondents indicated that the IFTA system is working well.

Although the IFTA survey responses of individual States are sometimes quoted in this report, States making particular responses are not identified. Forty two of the forty eight IFTA member States responded to the survey. States who responded are shown in the following figure.

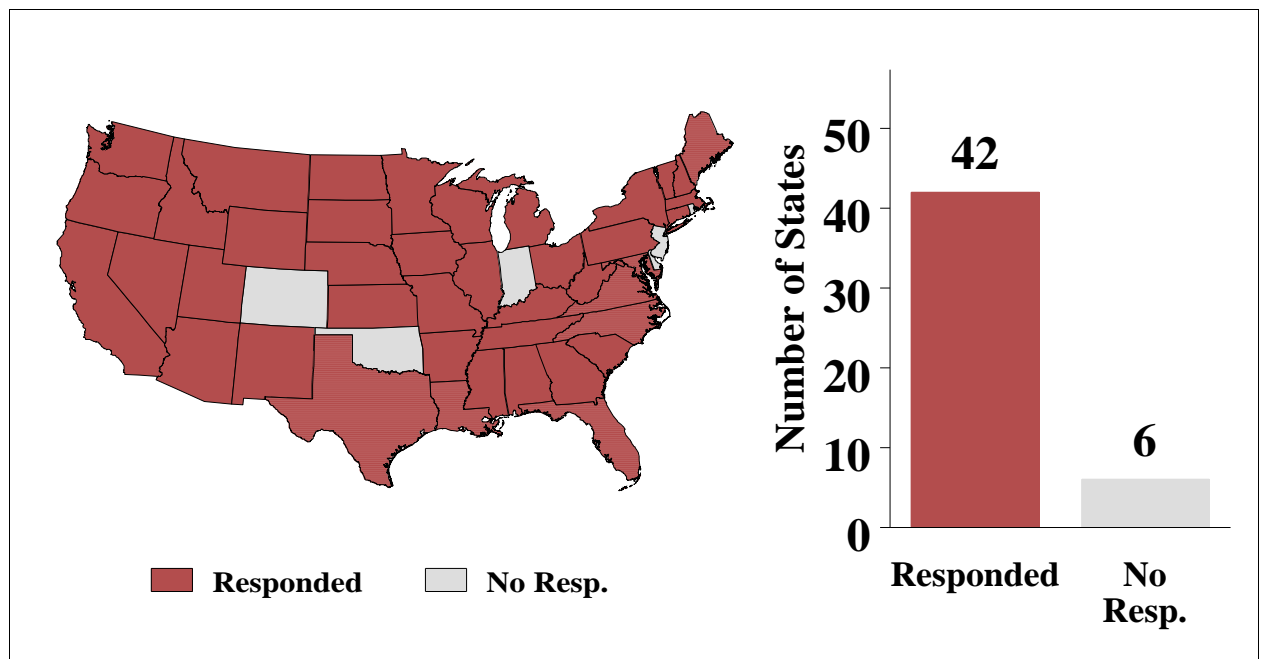

Figure ES-1. States responding to the FHWA's IFTA Survey, conducted January-April 2002. 


\section{Introduction}

The current Federal and State systems of fuel tax administration are the products of a long evolution. Today, all States report motor-fuel consumption and tax revenue data to the U.S. Federal Highway Administration (FHWA). That data is used, along with statutory formulas, to decide how Federal fuel tax revenues are apportioned to the States for use in various highway programs. Because of the Transportation Equity Act for the 21st Century (TEA-21) [1], the amount of Federal fuel tax revenue apportioned this way has increased from between one and two billion dollars annually in 1992-1997 to about twelve billion dollars annually today [2,3]. This is illustrated in Figure 1.

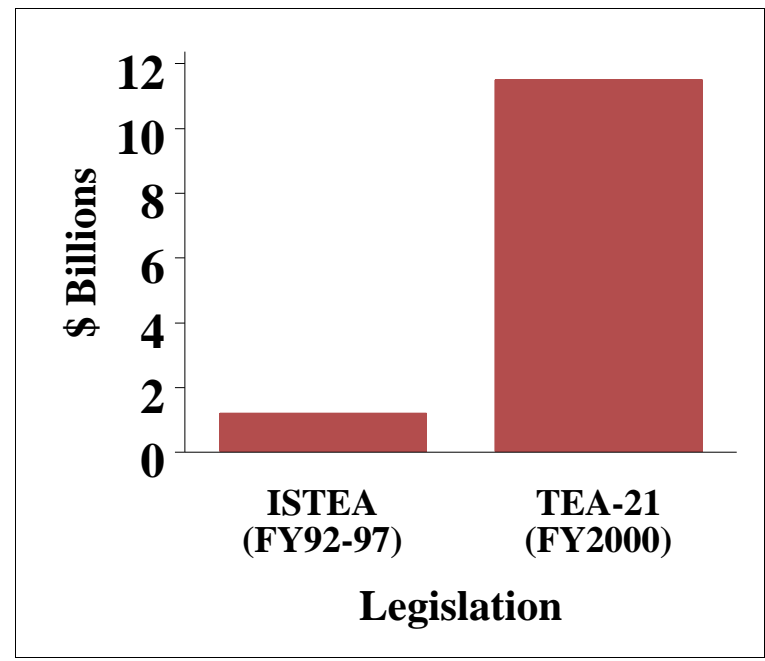

Figure 1. Average annual apportionments under ISTEA and TEA-21. (Source [3].)

Recognizing that it is in everyone's interest that data the States report to FHWA should be as accurate and timely as possible, FHWA has been reviewing its motor fuel data reporting system and the reporting instructions it provides to the States. A Federal Register notice [4] describes this review and proposed modifications to the data reporting system, as of August 2000. Accounting for International Fuel Tax Agreement Procedures (IFTA) is one of six issues specifically addressed in the notice. IFTA is a fuel tax collection agreement among the forty eight contiguous U.S. States and the ten Canadian Provinces. Under IFTA each motor carrier pays fuel taxes owed to possibly many jurisdictions only to his own base jurisdiction. The IFTA base jurisdictions then settle among themselves the taxes owed to them by carriers in all IFTA jurisdictions. This is is illustrated in Figure 2. IFTA, which is the subject of this report, is described in much greater detail below.

In the Federal Register notice, FHWA proposed to review and document "how States collect IFTA revenue, how States separate out revenues not related to the gallons of motor fuel and direct motor fuel gallon taxes, how they calculate net gallons and revenues, the time required to process IFTA data and report to the FHWA," and to "suggest alternatives for IFTA calculations if full data are not available." 


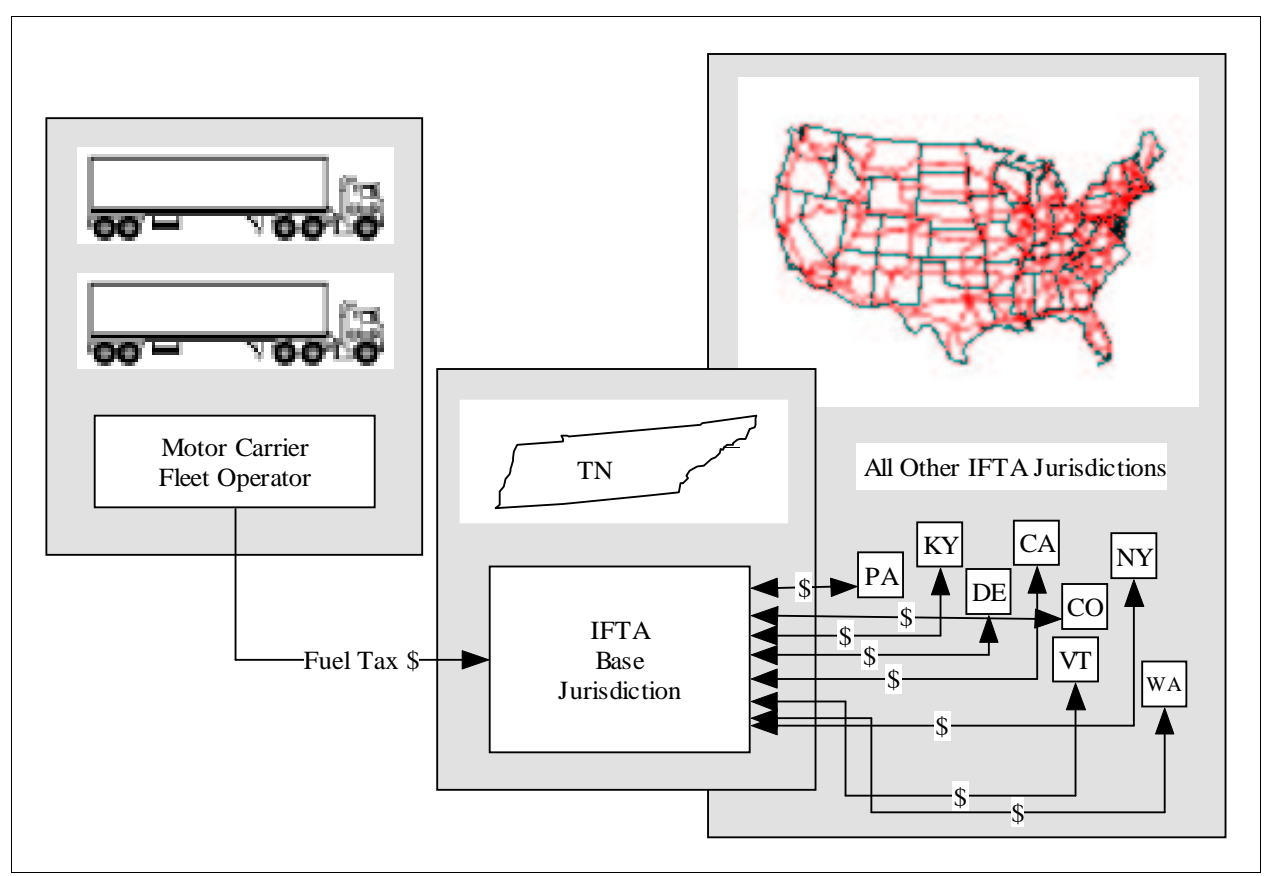

Figure 2. Simplified flow diagram of IFTA collections. Motor carrier pays base jurisdiction (in this example, Tennessee) what he owes all jurisdictions. Base jurisdiction settles with all other jurisdictions to balance payments for all motor carriers and all jurisdictions.

To accomplish these objectives, FHWA commissioned the Oak Ridge National Laboratory to conduct a survey of IFTA member States. This survey was conducted January-April 2002. The IFTA survey questionnaire was sent to all forty eight IFTA member States (all States except Alaska and Hawaii). The survey was divided into separate sections for IFTA collections and FHWA reporting, and both State IFTA collections and FHWA reporting personnel were contacted to take the survey. For each State, contacts were selected and initially contacted by the FHWA Division Administrator for the State. In some cases the same State contact handled both the collections and reporting sections. Survey questionnaires were delivered by email attachment and were returned by email, fax, or regular mail.

The survey was designed to help FHWA understand the States' IFTA data collection process and to identify obstacles the States may be encountering in timely and accurate reporting of IFTA fuel consumption data to FHWA. To focus the State responses on information that is most relevant to FHWA, instructions to the States stressed a four-part principle: For every gallon of motor fuel consumed in the nation, what FHWA ultimately tries to determine from the State data is (1) the type of the fuel (gas, diesel, etc.), (2) the State (or Province, territory, etc.) the fuel was consumed in, (3) whether the fuel was consumed on-highway or off-highway, and (4) when the fuel was consumed. Thus, for example, the survey focused on difficulties in dealing with late, incomplete, or inaccurate data, and not, for example, on accounting software used to compute IFTA totals.

Results of the IFTA survey together with the IFTA literature (e.g., the IFTA Procedures Manual) and the objectives listed in the Federal Register notice are the basis for this report. Section 2 is a general overview of IFTA and IFTA data reporting to FHWA. State-specific departures from the general overview are discussed in Sections 3-8. Section 3 describes in more detail how each State collects IFTA revenues. Section 4 is about how States separate out revenues not related to 
gallons of motor-fuel and direct motor-fuel gallon taxes. Section 5 describes how States calculate net IFTA gallons and the time delay in the processing. Section 6 is about difficulties in processing and reporting IFTA data. Timeliness is discussed further in Section 7, and alternatives for IFTA calculations if complete IFTA data are not available are discussed in Section 8. The survey questionnaire and instructions are in Appendices A and B.

Although the IFTA survey responses of individual States are sometimes quoted in this report, the responses are not identified by State. Forty two of forty eight IFTA member States responded to the survey. With a few exceptions, responses to the survey suggest that the IFTA collection mechanism works well and that IFTA totals are a good source of fuel consumption data for FHWA. Reasons for the exceptions include the use of off-road fuel volumes in IFTA mpg estimates, State-to-State differences in definitions of taxable mileage or taxable fuel, and inconsistencies in interpretations of "net taxable gallons." Details about these exceptions (including how mpg rates are calculated) are discussed in the report. 


\section{IFTA Data Reporting-General Background}

This section is a general overview of IFTA and IFTA data reporting to FHWA. IFTA is a fuel tax collection agreement among the forty eight contiguous U.S. States and ten Canadian Provinces. Before IFTA, each of these jurisdictions administered fuel tax collections using its own licensing, forms, and reporting and auditing procedures. As shown in Figure 2, under IFTA, motor carriers pay taxes directly to only one State or Province, their base jurisdiction, which they are licensed by. The IFTA member jurisdictions then settle and distribute collections among themselves. This simplifies the tax administration, and, for motor carriers, paperwork is reduced from as many as fifty eight separate sets of forms to only a single set. By the end of 1996, all forty eight contiguous States and the ten Canadian provinces had joined IFTA [5]. Hawaii, Alaska, and the District of Columbia ${ }^{1}$ are not members.

According to the IFTA Articles of Agreement [6], motor vehicles under the purview of IFTA are single or combination vehicles, other than recreational vehicles, that either exceed 26,000 pounds gross or registered vehicle weight or have power units with three or more axles. ${ }^{2}$ Although fueltax surcharges, which sometimes depend on vehicle weight (or weight class), are also paid through IFTA, for the most part, IFTA taxes are volume-based, not weight-based taxes. IFTAlicensed motor carriers display IFTA decals on both sides of their trucks, tractors, or buses. Although IFTA is designed primarily for inter-jurisdictional travel, IFTA collections may also be from licensees who travel exclusively within their base jurisdictions. However, many jurisdictions also offer non-IFTA alternatives (e.g., special use/trip permits, direct refunds for off-road use), particularly for carriers whose operations are exclusively intra-jurisdictional. (For example, Utah is such a State [7].)

Figure 3 is a flow chart that describes generally the process of IFTA data reporting by the States to FHWA. Because reporting processes differ among the States, Figure 3 and the discussion in this section are idealized generalizations that do not apply exactly to individual States. The intention in this section is to provide an overview of the IFTA reporting process. State-specific departures from the overview and details inferred from the IFTA survey are discussed later in the report.

The process of collecting and reporting IFTA data to FHWA has two components: (1) IFTA collections, which include both motor carrier return processing and State-to-State exchanges, and (2) IFTA data processing by the State agency that submits IFTA data along with other fuel tax and consumption information on Forms 551M and 556 to FHWA. The basis for the IFTA collections procedures is described in the IFTA Procedures Manual [8] and the IFTA Articles of Agreement [6]. The current basis for State fuel consumption reporting to FHWA is Chapter 2 of A Guide to Reporting Highway Statistics [9], particularly pages 2-4 and 2-5.

IFTA motor carrier returns (\#1 on the flow chart) list total and taxable mileages and taxable gallons of fuel consumed by State (or Province) and by fuel type. IFTA processing centers for each State (e.g., the New York Regional Processing Center or the State's own processing center)

\footnotetext{
${ }^{1}$ The District of Columbia has submitted an adopting resolution for IFTA membership with a July 1, 2002 implementation date [The IFTA News, Volume 80, September 2001].

${ }^{2}$ Any two-axle tractor and trailer (with any number of axles) with a combined gross vehicle weight of less than 26,000 pounds is not IFTA-qualified.
} 
collect returns from motor carriers in the State, and receive and distribute IFTA collections to and from IFTA processing centers for other States. Although monetary and reporting exchanges between States (\#2 on chart) are made monthly, reporting by motor carriers and most of the collections are done quarterly, by the end of the month following the end of each calendar quarter. Thus the IFTA reporting schedule is as in Table $1 .^{3}$

Table 1. IFTA Reporting Schedule

\begin{tabular}{|cc|}
\hline Quarter & $\begin{array}{c}\text { Due Date } \\
\text { for Reports }\end{array}$ \\
\hline January-March & April 30 \\
April-June & July 31 \\
July-September & October 31 \\
October-December & January 31 \\
\hline
\end{tabular}

IFTA exchanges among the States are due at the end of the second month after the end of each calendar quarter, that is, at the end of May, August, November, or February. Therefore, most payments between IFTA processing centers are made at the end of these four months. IFTA revenue totals are combined with non-IFTA fuel tax revenue totals (\#3 on chart), including revenue from taxes paid by wholesalers, distributors, and purely intrastate motor carriers, collected during the third month after the end of each calendar quarter (that is, June, September, December, or March) and reported (\#4 on chart) to the State agency that handles FHWA reporting.

Of course the primary unit in the IFTA collection process is dollars, not gallons, but gallons are generally carried along in IFTA accounting. Nevertheless, some States do not carry IFTAreported gallons all the way through to FHWA reports, but instead calculate consumption from revenue totals and tax rates. Although FHWA prefers that the IFTA gallons be carried all the way through, if gallons are not carried along, then revenue from penalties, interest, and other collections not directly proportional to gallons of fuel consumed are excluded from revenue totals used to calculate consumption.

Monthly IFTA collections also may include late payments and assessments. These payments are directly proportional to fuel consumed and are thus included in consumption totals reported to FHWA. To keep accounting reasonably simple, however, gallons associated with late payments and assessments are included with totals for the month in which the payments are collected, even though those gallons were actually consumed in earlier months.

By the end the third month after the end of each calendar quarter, each State's revenue department provides the State's FHWA reporting group with gross revenues or volumes by fuel type for that month (\#5 on chart), including revenue collected for tax-refunded mileage. The

\footnotetext{
${ }^{3}$ In response to survey question C5, survey respondents indicated without exception that the schedule in Table 1 was followed.
} 
State's IFTA collections center provides the FHWA reporting group with IFTA totals (\#6 on chart), including both total and taxable mileages incurred during the calendar quarter that ended three months earlier, for carriers based both in and outside the State. For the third month after the end of the quarter, that is, for June, September, December, or March, the FHWA reporting group uses the IFTA quarterly totals to adjust State totals to reflect actual fuel consumption in the State.

Thus, although the IFTA adjustments are posted only every three months, they actually represent an entire calendar quarter. For June, September, December, or March, the IFTA-adjusted totals are reported on form 551M (\#7 on chart) to FHWA no more than ninety days from the end of the month, that is, by the end of August, December, March, or June. Many States take less than ninety days to file the reports, however.

Revenue totals are reported annually on form FHWA-556 (\#8 on chart) and used to verify or reconcile volume totals for the corresponding twelve monthly 551M forms. Included on the Form 556 are IFTA amounts or credits paid to or received from other States, as well as totals for fines, penalties, interest, decal fees, in lieu of volume taxes, assessments, and so on, all of which may have IFTA components. The 556 forms for a particular year are due April 1 of the following year, if reporting is for a calendar year, or January 1, if reporting is for the State's previous fiscal year. 
Interstate motor carriers file IFTA returns (e.g.,

IFTA-100-MN) to base State by end of month $\mathrm{m}+1$, for calendar quarters ending month $\mathrm{m}(\mathrm{m}=3,6,9,12)$.

Late returns and assessment \$'s are also submitted.

Low IFTA mileage filers may file only annually.
Other (non-IFTA)

fuel taxpayers

(distributors,

wholesalers, intra-state motor carriers) file returns during month $\mathrm{m}+3$.

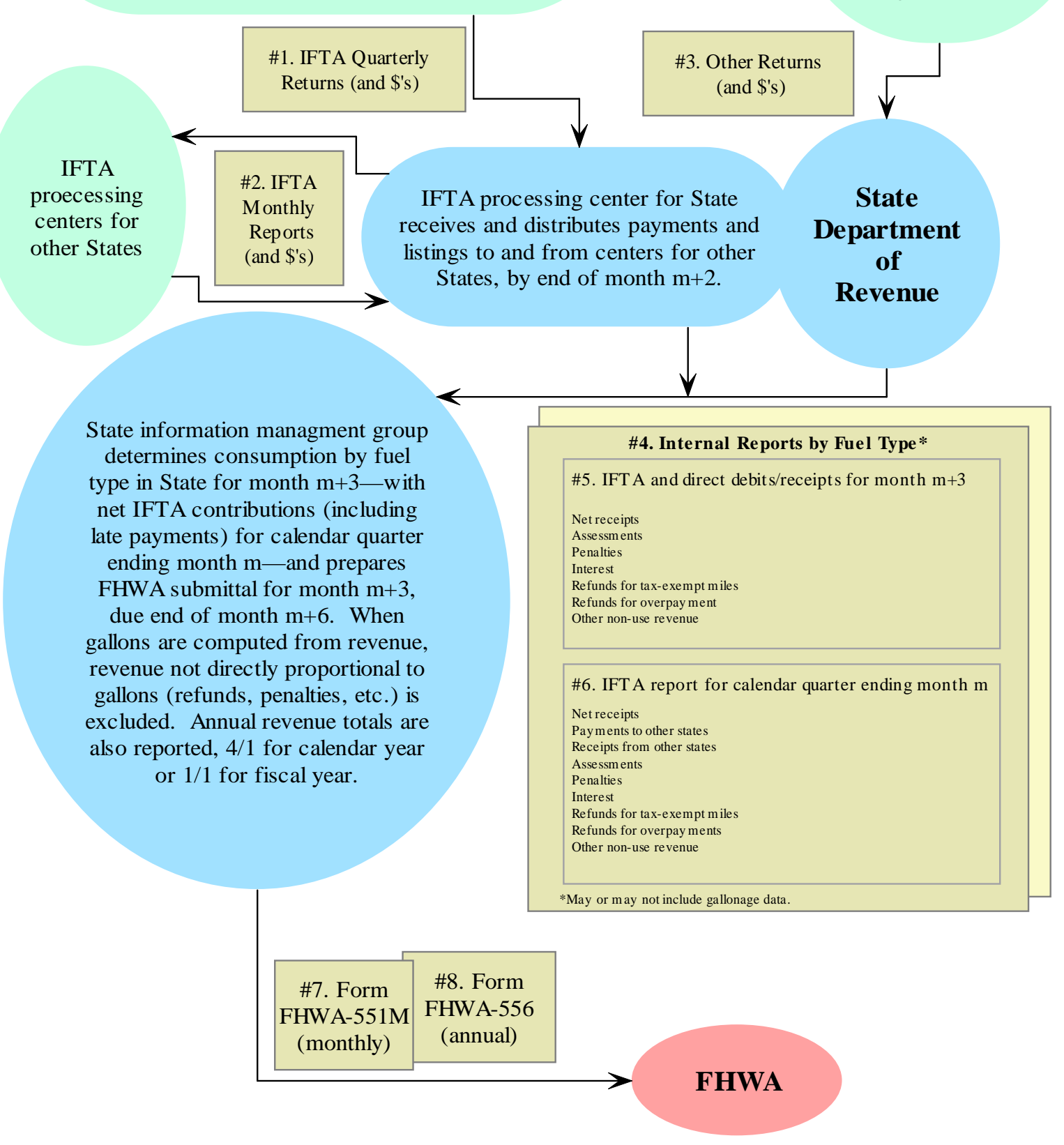

Figure 3. The flow of IFTA fuel consumption information to FHWA-a generalization (not exact for individual States) 


\section{How Each State Collects IFTA Revenues}

The IFTA Articles of Agreement and Procedures Manual carefully articulate IFTA's contractual terms and motor carrier responsibilities for reporting, record keeping, and maintenance of datarecording (e.g., electronic vehicle tracking) systems. Thus IFTA collections processes tend to vary little from State to State. IFTA reporting forms do vary slightly with jurisdiction, but essentially the same information is reported to all IFTA member States. IFTA licenses are issued for fleets of one or more IFTA-qualified vehicles. Generally, quarterly IFTA returns are filed for each IFTA license.

One section of the IFTA return form is for fleet mileage and fuel consumption totals for all jurisdictions for the fleet of vehicles operating under the corresponding IFTA license. For each fuel type used in the quarter, the IFTA returns have entries for all-jurisdiction total (both taxable and tax-exempt) mileage, all-jurisdiction total (taxable and tax-exempt) gallons, and their ratio, the average fleet mileage-per-gallon (mpg) for the quarter.

A second section of the IFTA return is for jurisdiction-specific entries, essentially:

\begin{tabular}{|c|c|c|c|c|c|c|c|c|c|}
\hline $\mathbf{1}$ & $\mathbf{2}$ & $\mathbf{3}$ & $\mathbf{4}$ & $\mathbf{5}$ & $\mathbf{6}$ & $\mathbf{7}$ & $\mathbf{8}$ & $\mathbf{9}$ & $\mathbf{1 0}$ \\
\hline $\begin{array}{c}\text { Juris- } \\
\text { diction }\end{array}$ & $\begin{array}{c}\text { Fuel } \\
\text { type }\end{array}$ & $\begin{array}{c}\text { Total } \\
\text { miles }\end{array}$ & $\begin{array}{c}\text { Taxable } \\
\text { miles }\end{array}$ & $\begin{array}{l}\text { Taxable } \\
\text { gallons }\end{array}$ & $\begin{array}{c}\text { Tax- } \\
\text { paid } \\
\text { gallons }\end{array}$ & $\begin{array}{c}\text { Net } \\
\text { taxable } \\
\text { gallons }\end{array}$ & $\begin{array}{c}\text { Tax } \\
\text { due } \\
\text { (or credit) }\end{array}$ & Interest & $\begin{array}{c}\text { Total } \\
\text { due } \\
\text { (or credit) }\end{array}$ \\
\hline
\end{tabular}

For each jurisdiction (1) and fuel type (2), carriers report total mileages (3) and taxable mileages (4). "Total miles" and "Taxable miles" are determined from odometer readings or other instrumentation (e.g., global positioning systems). "Total miles" includes off and private-road use; "Taxable miles" generally excludes it. Taxable gallons (5) are also reported, which are computed by dividing the taxable mileages in the jurisdiction by the average fleet mpg rate for the fuel type, which was recorded in the all-jurisdiction-totals section of the return. Note that fleetwide averages are used to compute mpg rates, though there may be considerable variability in gross vehicle weights or vehicle types among multiple vehicles in a fleet.

Tax-paid gallons (6) (e.g., gallons purchased at service stations) are recorded, and net taxable gallons (7) (i.e., taxable gallons less tax-paid gallons) are also reported, along with taxes due (8), interest (9), and the total due (10), which, if a motor carrier purchases more fuel in a jurisdiction than he consumes there, may be negative. Note that "tax-paid gallons" refers here to all gallons for which taxes have been paid, regardless of whether their ultimate usage is taxable.

Other sections of the IFTA return have entries for non-IFTA jurisdictions, credits for taxrefunded fuel use, and identification information.

The volumes reported by the IFTA motor carriers, other than the all-jurisdiction total volumes and the per-jurisdiction tax-paid gallons, are actually estimates. The per-jurisdiction reported taxable gallons are estimates computed by dividing per-jurisdiction taxable mileages by mpg rate averages computed from the all-jurisdiction mileage and volume totals. Thus, although the total volumes reported by motor carriers are likely to be accurate, volumes computed for individual jurisdictions may be lower or higher than volumes actually consumed. 
For example, if interstate carrier $\mathrm{X}$ goes six miles per gallon on average, but because of topography, elevation, traffic density, etc., only three miles per gallon in jurisdiction $\mathrm{Y}$, then $\mathrm{X}$ could travel six miles and consume two gallons of fuel in Y, and yet, according to X's IFTA quarterly return, owe $\mathrm{Y}$ the tax on only one gallon. Note also that another carrier $\mathrm{Z}$ who operates at three mpg exclusively within $\mathrm{Y}$ would then pay fuel tax to $\mathrm{Y}$ at a higher rate per mile than $\mathrm{X}$ does. On the other hand, for each carrier, volume estimates computed on the basis of overall mpg rates are directly proportional to the carrier's mileage, and, because of differences in mpg rates from one jurisdiction to another, reflect mileages better than actual volumes would.

Because the jurisdiction-specific gallon estimates reported on the IFTA returns are computed from taxable mileages, the gallons estimates are of taxable (not total) gallons. Although a total gallon estimate could be computed from the total mileage and the overall average mpg rate, total gallon estimates are not entered on the IFTA returns. This point will be revisited in Section 5.

The information reported by motor carriers is compiled by the IFTA jurisdictions into reports, using software such as VISTA/TS (Vehicle Information System for Tax Apportionment / Tax System). ${ }^{4}$ Report items include total mileage, taxable mileage, mpg, taxable gallons, tax-paid gallons, net taxable gallons, tax due, interest, and totals for taxes due, audits, interest, and surcharges. There was no entry for total volume (or total volume estimate) on the VISTA/TS report from Tennessee, examined for this report.

Responses to several of the questions on the collections part of the IFTA survey suggest that there are few impediments to the smooth operation of the IFTA collection process. The first collections question $(\mathrm{C} 1)$ on the survey was

\section{C1. What obstacles (if any) does your State encounter in following the IFTA Procedures Manual (http://www.iftach.org/recod/pm.pdf) or the IFTA process in general?}

Figure 4 summarizes the responses to question $\mathrm{C} 1$. Most of the survey respondents answered "None" or the equivalent to this question. ${ }^{5}$ Nearly all of the "Other" responses to question C1 involved either IFTA's extensive auditing requirement, which would only effect FHWA reporting indirectly, or routine issues such as verification and enforcement, scheduling, and resources for data entry. One State listed several issues that directly relate to the accuracy of data reported to FHWA (and the four-part principle):

-1. Different methods of calculating volumes by different states. 2. Some states allow exemptions (for miles), some don't. 3. States that don't pay transmittal invoices are not paid according to IFTA rules.

Of course the goal in FHWA's fuel-use attribution accounting is to properly account for such State-to-State differences in the collections process.

\footnotetext{
${ }^{4}$ A sample VISTA/TS report for Tennessee was kindly provided by Ms. Ginny Ricketts, Commercial Vehicle Division, Tennessee Department of Safety.

${ }^{5}$ Nonresponses are abbreviated "No Resp." in Figure 4 and other figures in this report.
} 


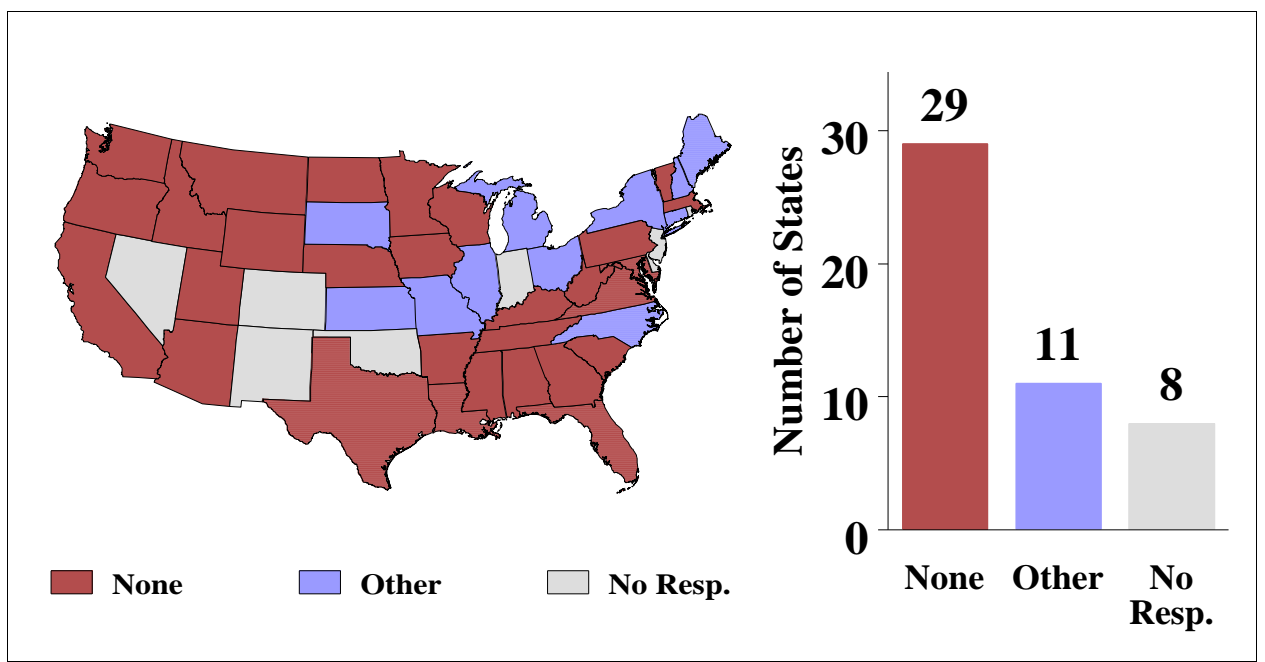

Figure 4. Responses to IFTA survey question C1 (see above).

To ensure that carriers comply with IFTA reporting requirements, they are required to maintain individual vehicle mileage and fuel purchase records [8]. Vehicle mileage records include, for each trip and jurisdiction, mileages by jurisdiction, starting and ending dates, route of travel, and, for all fuel purchases or receipts, the date, quantity, price, and type of fuel purchased, and the person from whom fuel was purchased or received. Bulk fuel purchase and inventory records must be maintained to substantiate tax payments for the bulk purchases. IFTA licensees are required to maintain these records for four years, and IFTA requirements call for each jurisdiction to audit an average three percent of its accounts per year [10].

Question C4 on the IFTA survey was similar to C1, but was about procedural departures rather than obstacles:

\section{C4. What departures, if any, does your State usually take from the IFTA Procedures Manual or from what you understand to be IFTA procedures typical for other States?}

Figure 5 shows that again, respondents mentioned very few variances from the prescribed IFTA system.

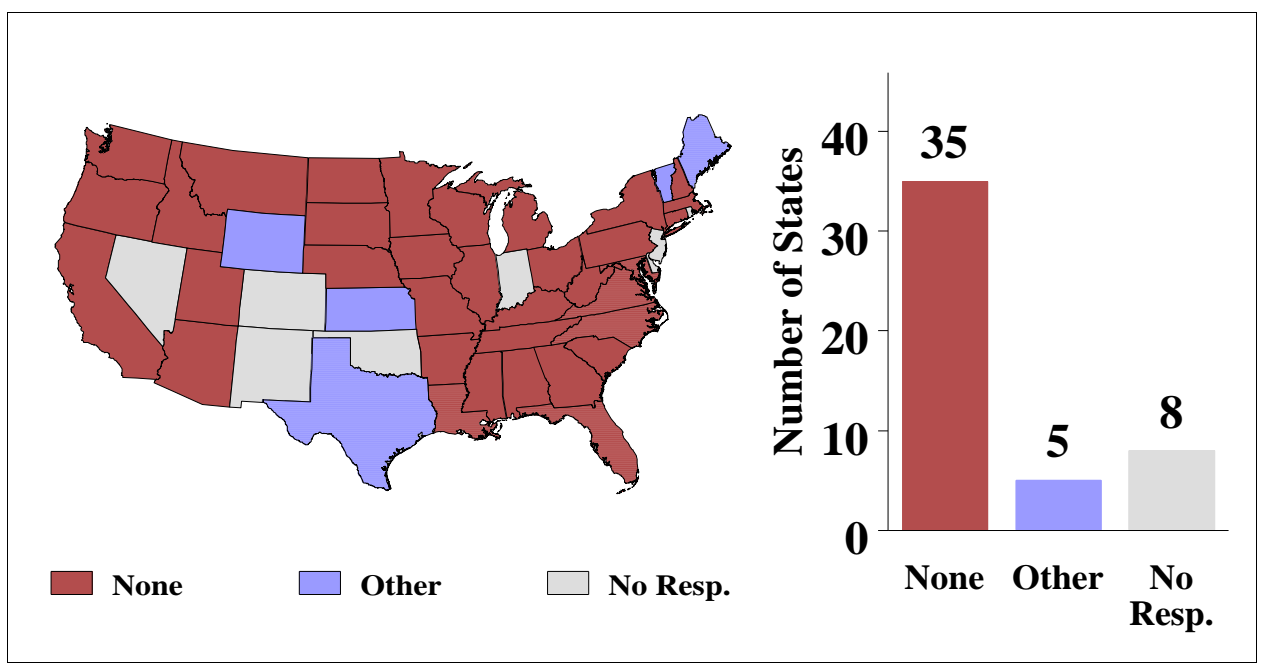

Figure 5. Responses to IFTA survey question C4 (see above). 
None of the "Other" responses to this question seemed to directly bear on the accuracy of data reported to FHWA.

Question C3 on the survey was

\section{C3. Please describe any special circumstances that make IFTA reporting for your State different from or more difficult than for other States.}

Results for Question C3 are summarized in Figure 6.

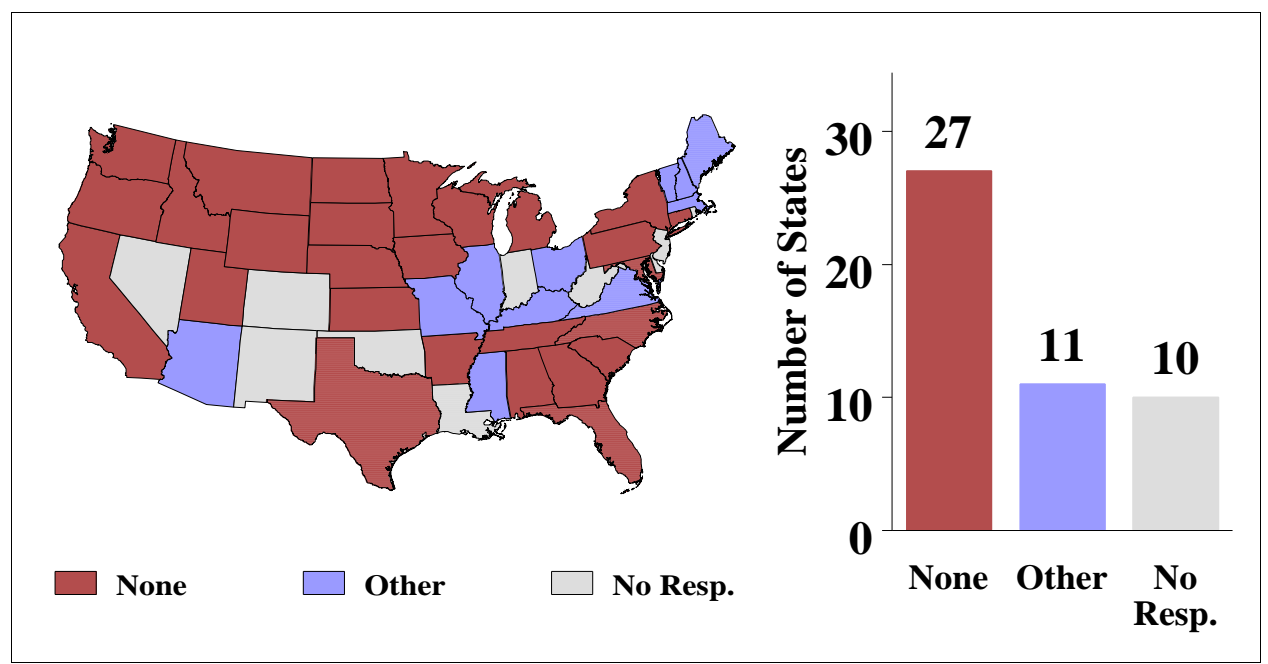

Figure 6. Responses to IFTA survey question C3 (see above).

Again, the survey suggests that circumstances making IFTA reporting different or difficult are unusual, though there are exceptions:

-[Our State] does not require gasoline reporting in IFTA. [Our State] pre-edits all incoming tax returns for mathematical accuracy prior to data entry. We provide the IFTA 101 in spreadsheet format on our web site and by mass e-mail to about 300 [of our State's] taxpayers.

—Massachusetts has a mileage deduction for traveling on the "Massachusetts Turnpike."

-IFTA Collections may not be recognized as revenue each month. IFTA funds are deposited into and paid out of a clearing account and are only recognized as revenue when transferred to [our State's] DOT.

-We are forcing customers to use fuel consumed off road in calculating mpg factor.

- [Our State] is one of five IFTA jurisdictions that has a fuel use tax surcharge. Because we do not impose a fuel use tax or reporting requirements on buses and two-axle trucks over 26,000 pounds GVW we cannot calculate the net gallons consumed by these vehicles on [our State's] roads.

- [Our State], for example, exempts [our State's] registered agricultural vehicles and [our State's] registered buses from reporting their mileage. Other states do not have the 
same exemptions therefore they [the carriers] are required to have the IFTA and report mileage to those states. [Our State] is responsible for issuing permits to the carrier and also generating an IFTA report. This causes confusion on the carrier's part and they may end up filing mileage and taking tax credit for all states including [our State]. This can go undetected until the performance of an audit.

-The collection of [our State's] surtax.

-Exemption from tax of purchases of 1,000 gallons or more of fuel by interstate motor carriers when such fuel is delivered in bulk quantities into their fuel storage tanks.

A few clarifications about these last comments: Under Massachusetts General Law, the Massachusetts Turnpike is not part of the Massachusetts State highway system, and, according to Chapter 64A, Section 7 on fuel taxation [11], the turnpike "shall not be considered a highway for the purposes of this chapter." Thus, technically, fuel consumption on the Massachusetts Turnpike is non-highway use, and IFTA motor carriers can report Massachusetts Turnpike travel as taxexempt [12].

Because off-road mpg rates are usually lower than on-road rates, including off-road fuel use in IFTA mpg estimates tends to lower overall mpg estimates and, in turn, to inflate jurisdictionspecific taxable gallon estimates. This is of concern to truckers, as one State pointed out, and should also be of concern to FHWA in attribution calculations. Because FHWA is ultimately interested in attribution proportions (as opposed to totals), volume totals that are all inflated in the same proportion would not translate to errors in attribution, but inflations that are disproportionate because of State-to-State variations in the amount of off-road usage should be of concern, and inflated totals could also be of concern in reconciling on and off-road fuel use estimates.

Oregon's response to Question C3 suggests that Oregon's weight-mileage system does not introduce difficulties into the IFTA collection system. Similarly, surcharges imposed by other State's are also accounted for on IFTA returns, and thus should (in theory) be accounted for in fuel consumption reporting to FHWA.

However, several of the other special circumstances mentioned by the States, such as Ohio's exemptions for IFTA-qualified buses or two-axle trucks, may require special handling in FHWA's attribution accounting. Political, economic, and geographic differences from State to State are, of course, bound to result in differences. Here are several other examples of actual or potential differences:

- Although the definition of taxable mileage generally excludes private-road, off-road, and non-highway (e.g., power take off) use, the definition depends on the jurisdiction. In Idaho, usage on privately maintained roads on private property is not taxable [13]; in Connecticut all miles are taxable [14].

- Although the IFTA reporting periods are calendar quarters (see Table 1) and quarterly reporting is generally required, the Articles allow for annual rather than quarterly reporting, at the discretion of the base jurisdiction and subject to the approval of affected member jurisdictions, for licensees whose operations during twelve consecutive months in jurisdictions other than their base jurisdiction total less than 5,000 miles. Some States 
(e.g., Kentucky) do not allow annual reporting; some States (e.g., Missouri) do. For annual reporting, it is clear that fuel consumption data cannot be reported within "90 days after the close of the month for which the data are being reported," as specified in the Guide to Reporting Highway Statistics [9].

- Although the IFTA Articles and Procedures Manual exclude recreational vehicles, they do not expressly qualify IFTA vehicles as "commercial," "for business," or the equivalent. Thus, public use (e.g., State, county, or municipal) vehicles appear to qualify. Although some States do expressly qualify IFTA vehicles as commercial, ${ }^{6}$ not all do, and it is not clear that States might not include public fuel use with IFTA fuel use in the future. ${ }^{7}$

Question C6 on the collections part of the survey is about irregularities:

C6. Do you find any irregularities or inconsistencies from month to month, quarter to quarter, or year to year, in IFTA revenue collections? If so please offer suggestions, comments, facts, opinions, etc.

As Figure 7 shows, responses to this question suggest that the IFTA collections personnel generally see the system as running smoothly. Exceptions were mentioned for computer problems and data entry problems, changing economic conditions, and auditing. Strictly seasonal effects and periodic behavior due to the IFTA quarterly reporting cycle were also mentioned, but for Figure 7, seasonal and quarterly-reporting effects are considered as given, and those responses were not used to place a State in the "Other" category in Figure 7.

FHWA has demonstrated scenarios under which monetary gains could potentially be achieved by carriers who misrepresent IFTA highway mileages as having been in one State when the mileages were actually incurred in another State with a higher fuel tax rate. ${ }^{8}$ (The scenarios assume that similar-length trips could be taken through either state, and that there is an advantage to the carrier to taking the trip through the state with the higher fuel tax rate.) The responses to survey Question C6 suggest that this kind of misrepresentation is not seen by the States as an important issue by-with a few qualifications:

\section{C10. Do you think that motor carriers are claiming higher mileages in States with low fuel tax rates than they would if State fuel tax rates were uniform?}

As Figure 8 indicates, the responses to this question suggest that for the most part State to State

\footnotetext{
${ }^{6}$ The IFTA Articles specify that "Any person based in a member jurisdiction operating a qualified motor vehicle(s) in two or more member jurisdictions is required to license under this Agreement..." Florida, on the other hand, requires IFTA carriers to "have an established place of business in Florida from which motor carrier operations are performed" (http://www.hsmv.state.fl.us/dmv/faqcarriers.html). Washington's IFTA guidance (http://www.wa.gov/dol/forms/441242.pdf) explicitly describes an IFTA qualified vehicle as "a commercial vehicle that exceeds $26,000 \mathrm{lbs}$. gvw and operates interstate..."

${ }^{7}$ Note that this bears on the issue "Reporting of Public Use of Diesel Fuel," which, along with IFTA, is one of the six issues discussed in the Federal Register notice [4] mentioned in Section 1 of this report.

${ }^{8}$ Personal communication with Tom Howard, Laureen Fung, and Ralph Erickson.
} 
variations in fuel tax rates are not seen as causing reporting irregularities. ${ }^{9}$ The qualification is the number of people who, though the question is prefaced with "do you think," nevertheless responded with "no evidence" or the equivalent (abbreviated as "No Evid." in Figure 8.). Perhaps the survey respondents were reluctant to state anything they did not have data to support. Only

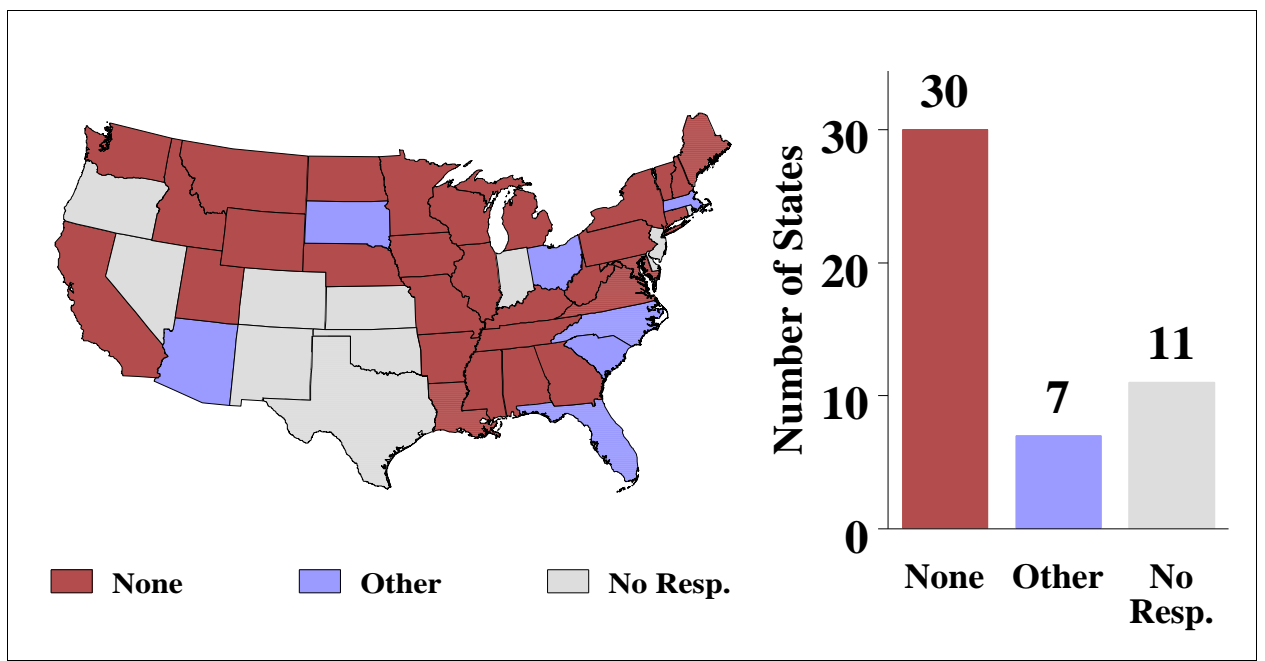

Figure 7. Responses to IFTA survey question C6 (see above).

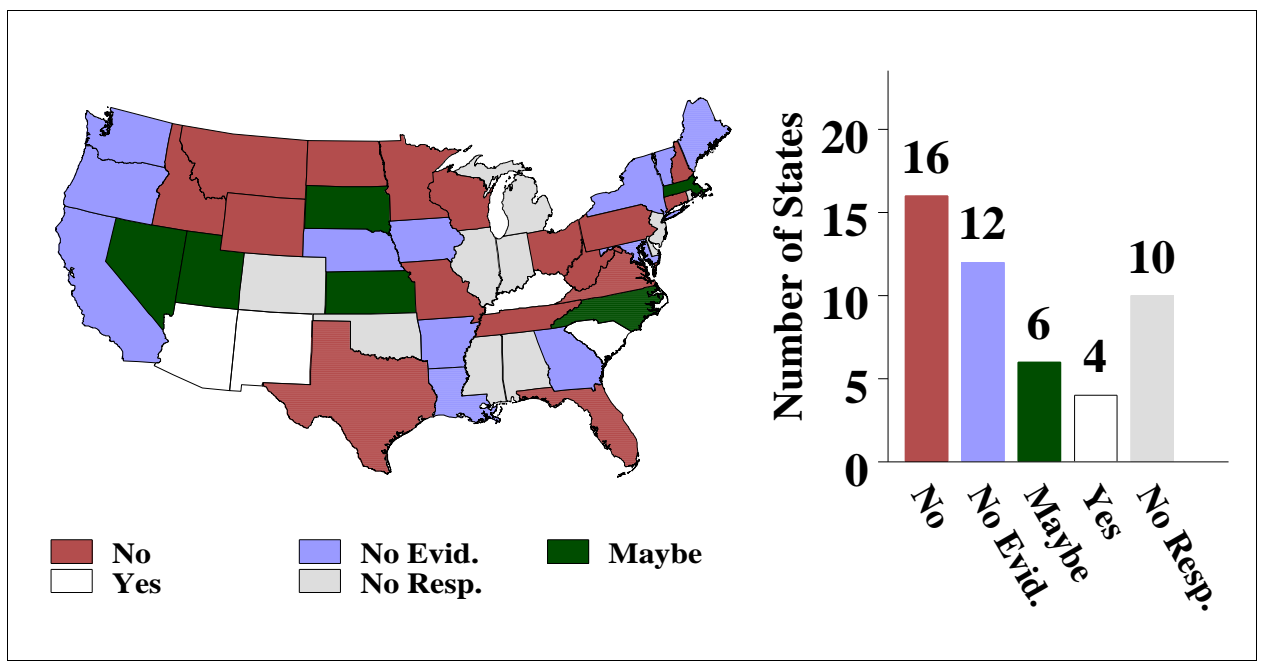

Figure 8. Responses to IFTA survey question C10 (see above).

four States actually responded in the affirmative to this question. Nevertheless, these four, along with the "Maybes" and "No Evidences" suggest that data misreporting is at least potentially a problem.

IFTA reporting procedures suggest that there is a potential for abuse. According to the Section P540 (DISTANCE RECORDS) of the IFTA Procedures Manual, carriers are required to record, for each trip and jurisdiction, starting and ending dates, mileages by jurisdiction, and the route of

${ }^{9}$ Collection question C10 was also posed as question R6 on the FHWA reporting part of the survey. Here, responses to either $\mathrm{C} 10$ or $\mathrm{R} 6$ are considered together. 
travel. According to Section P550 (FUEL RECORDS), they are required to record, for all fuel purchases or receipts, the date, quantity, price, and type of fuel purchased, and the person from whom the fuel was purchased or received. Carriers are not required to record dates other than the trip start and end dates and fuel-purchase dates, and they are not required to record times-of-day. With fuel tank capacities of over 200 gallons, at 5-7 mpg, truckers can go over 1000 miles without refueling. Thus it seems possible that a trucker who is careful about where he refuels could report to IFTA actual trip start and end points and actual refueling dates and locations, and yet still misrepresent his actual route - to the tax advantage of the trucker and with little or no evidence to the contrary either in IFTA records or elsewhere. Motivation for doing this might be, for example, that the route actually taken had less congestion and higher speed limits than the route reported, which had lower fuel tax rates. IFTA auditing would not detect the transgression.

Despite this potential for mileage misreporting, it is worth stressing again that the responses to survey Question C10 suggest that mileage misreporting is not seen by the States as an important issue. This was in fact confirmed in a survey conducted by IFTA, Inc. subsequent to this one. ${ }^{10}$

One other question, C8, on the IFTA survey was specifically about IFTA collections:

\section{C8. Are IFTA payments to and from your State generally on time? If not, please offer suggestions, comments, facts, your own opinions, etc.}

Among the 38 States responding to this question, only one State suggested that timeliness might be an issue in IFTA collections, and even that one State was noncommittal:

- Some states are always early and some are always late.

Timeliness is discussed further in Section 7.

\footnotetext{
${ }^{10}$ Survey results kindly provided by Lonette Turner, IFTA, Inc. through Tom Howard, FHWA.
} 


\section{How Each State Separates out Revenues Not Related to Gallons of Motor-fuel and Direct Motor-fuel Gallon Taxes}

Question R2 on the FHWA reporting section of the IFTA survey was

R2. If applicable, please describe how your State separates out IFTA revenues not directly proportional to volumes of motor-fuel (penalties, interest, decal fees, refunds for overpayments, etc.) from direct IFTA motor-fuel gallon taxes?

As discussed in the previous section of this report, fuel type, jurisdiction, and taxable status of fuels (and calendar quarter) are all accounted for on IFTA motor carrier quarterly returns. Indirect fuel tax revenues such as interest, penalties, refunds for taxes reported for tax-refunded milage, and licensing fees are accounted for separately. In theory then, indirect fuel tax revenues could be tracked separately from tax revenue directly proportional to consumption.

Many of the responses to question R2 suggest that, indeed, keeping separate track of direct and indirect revenue streams is not a problem:

-Process is based on taxpayer-accountant process. Non-fuel related payments are taken care of. Apparently this is not a problem in [our State].

-[Our State] reports identify tax, penalty, interest, etc. separately.

-The revenues collected as a result of the IFTA program are coded specifically to the IFTA program and are identified to the specific source (i.e. decal fees, accounts receivable, returns processing, etc.). Each source has a code that enables the Department to identify how much revenue has been received from a particular source.

-Penalties and interest are identified separately in the information reported to the [our State's] Transportation Department by [our State's] Tax Commission and so should be reported separately as penalties and interest in form 556 and should not be reflected in any way in form $551 \mathrm{~m}$. Decal fees and distributors allowance are not reflected in the data reported to [our State's] Transportation Department by [our State's] Tax Commission.

—Line items on returns separate interest. Batch types separate decal fees.

-Amounts reported should just be taxes. Totals for other revenues are computed separately.

- There are subcodes to reflect all of the above.

-Our system tracks each fee and fee type separately (penalty, interest, tax, decals). Since the data is separated only tax fees are used for revenue figures for FHWA. Other fees such as penalty, interest, decals are not included in the revenue figures.

On the other hand, several of the responses to question R2 indicate that direct and indirect fuel tax accounting are not always separated: 
-The refunds, penalties and interest are maintained separate from the motor fuel gallons. What is received on transmittals from other jurisdictions on a monthly basis would contain any interest.

-Decal and permit fees and refunds are removed, however penalties and interest, if applicable, are not identified.

- [Our State] does not separate the IFTA volumes and revenues from the gross taxable gallonages.

—We do not separate penalties and interest. Decal fees and refunds are accounted for separately.

Apparently, at least for some States, direct and indirect fuel tax revenues are commingled in the accounting ultimately used to complete the FHWA 551M forms.

Responses to survey question C7 also show that there is at least a potential for commingling interest and penalties with direct tax revenues in the revenue accounting:

\section{C7. Do checks sent from your State to other States include payments not directly proportional to volumes consumed (for example, for penalties, interest, or refunds for overpayments)?}

Figure 9 shows that most States answered "yes" to question C7.

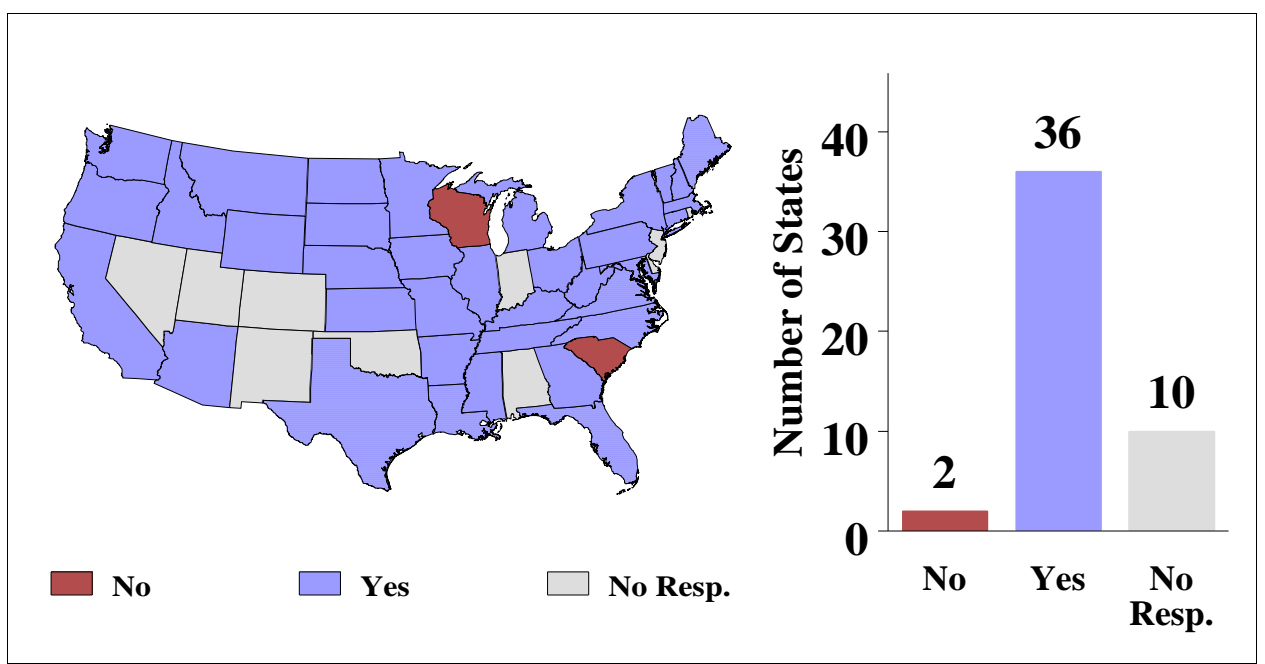

Figure 9. Responses to IFTA survey question C7 (see above).

Of course just exchanging checks that combine payments for direct and indirect fuel tax revenues does not imply that the complete IFTA accounting information is lost in its passage to the FHWA $551 \mathrm{M}$ reports. From the responses to question R2, however, it seems likely that it is being lost for some States, particularly for IFTA revenues from out-of-State. Nevertheless, the direct and indirect IFTA revenues are initially separate, and thus separate accounting could, in theory, be included with IFTA exchanges and passed on to the State revenue departments and ultimately to the State personnel who file the fuel consumption reports to FHWA. 


\section{How Each State Calculates Net IFTA Gallons}

According to the Guide to Reporting Highway Statistics, the gross volume reported on line 1 of the FHWA 551M form should be adjusted to reflect actual fuel use. The gross volume, which is "the total consumption of motor fuel within the State during the month," should be calculated as

$$
\begin{aligned}
\text { Gross Volume }= & \text { Gross sales from seller returns } \\
& + \text { IFTA fuel used in State } \\
& \text { - IFTA fuel purchased tax paid in State. }
\end{aligned}
$$

(Equation 1)

The gross volume here refers to all volumes, regardless of taxable status-it is broken into taxexempt, tax-refunded, and net volume taxed categories on lines 2 through 5 of the $551 \mathrm{M}$ form. The purpose of the two IFTA terms in Equation 1 is to adjust the gross sales from seller returns (the volume sold in the State) to reflect the volume actually used in the State. According to the Guide, this IFTA adjustment to the gross sales should be the sum of the "net taxable gallons (positive or negative) accumulated from all the base-State carrier returns" for the period, where

$$
\begin{aligned}
\text { FWHA Net Taxable Gallons }= & \text { Taxable gallons used in State } \\
& - \text { Tax-paid taxable gallons purchased in State } \\
& - \text { Tax-due (taxable) gallons purchased in State. }
\end{aligned}
$$

Thus the FHWA IFTA adjustment pertains specifically to the net volume taxed 551M category.

As discussed in Section 3 of this report, IFTA motor carriers report total fuel volumes used in all jurisdictions, but jurisdiction-specific volume estimates are reported only for taxable gallons, and taxable but not total volume estimates are on the State IFTA (e.g., VISTA/TS) summaries. On the IFTA motor carrier returns and in the IFTA reports, "net taxable gallons" refers to the difference between taxable gallons and tax-paid gallons, where tax-paid gallons refers to all gallons, whether taxable or not:

$$
\begin{aligned}
\text { IFTA Net Taxable Gallons }= & \text { Taxable gallons used in State } \\
& - \text { Tax-paid taxable gallons purchased in State } \\
& - \text { Tax-paid tax-refunded gallons purchased in State. }
\end{aligned}
$$

By direct subtraction, the FHWA Net Taxable Gallons and IFTA Net Taxable Gallons differ by the gallons purchased tax-refunded (e.g., gallons purchased tax-paid for off-road use) less the gallons purchased tax-due. This is illustrated in Table 2.

Thus, the FHWA net taxable gallons refers to the difference between taxable gallons used and taxable gallons purchased. In the language of IFTA, on the other hand, "net taxable gallons" refers to a balance of gallons on which taxes are due. The difference, which is equal to the volume purchased tax-refunded less the volume purchased tax-due, is the amount by which 


\begin{tabular}{|c|c|c|c|c|}
\hline \multicolumn{5}{|c|}{ FHWA Net Taxable Gallons } \\
\hline & \multicolumn{2}{|c|}{ Taxable } & \multirow{2}{*}{$\begin{array}{l}\text { Tax-Refunded } \\
\text { (and Tax-Paid) }\end{array}$} & \multirow{2}{*}{ Total Gallons } \\
\hline & Tax-Paid & Tax-Due & & \\
\hline Used & $\checkmark$ & $\checkmark$ & & Taxable \\
\hline \multirow[t]{2}{*}{ Purchased } & $\checkmark$ & $\checkmark$ & & Taxable \\
\hline & & & & Difference $=$ FHWA Net Taxable \\
\hline \multicolumn{5}{|c|}{ IFTA Net Taxable Gallons } \\
\hline & \multicolumn{2}{|c|}{ Taxable } & Tax-Refunded & \multirow{2}{*}{ Total Gallons } \\
\hline & Tax-Paid & Tax-Due & (and Tax-Paid) & \\
\hline Used & $\checkmark$ & $\checkmark$ & & Taxable \\
\hline \multirow[t]{2}{*}{ Purchased } & $\checkmark$ & & $s$ & Tax-Paid \\
\hline & & & & Difference $=$ IFTA Net Taxable \\
\hline & $\begin{array}{l}\text { Difference } \\
\text { allons Pur }\end{array}$ & $\begin{array}{l}\text { between } \mathbf{F} \\
\text { hased Tax }\end{array}$ & $\begin{array}{l}\text { WA and IFTA } \\
\text { efunded - Gal }\end{array}$ & $\begin{array}{l}\text { et Taxable Gallons = } \\
\text { ns Purchased Tax-Due }\end{array}$ \\
\hline
\end{tabular}

the IFTA Net Taxable Gallons differs from the IFTA adjustment sought by FHWA for the 551M forms. ${ }^{11}$

How each State calculates net IFTA gallons was specifically addressed in the IFTA survey question R1:

\section{R1. Please describe how your State calculates net IFTA volumes and revenues.}

Because of the difficulty for individual State personnel to understand the entire sequence of fuel tax data collection and reporting to FHWA, particularly in the context of FHWA's objectives (e.g., the four-part principle), this was not an easy question. Some of the responses were sketchy. Nevertheless, some of the responses were very helpful:

$-M P G$ is calculated using total miles and total gallons consumed. The MPG is applied to the mileage reported in each jurisdiction to determine the number of taxable gallons. The figure is multiplied by the current tax rate for the jurisdiction to determine the tax due for the jurisdiction.

\footnotetext{
${ }^{11}$ Note that the tax-paid tax-refunded term also could not properly apply to the $551 \mathrm{M}$ tax-refunded fuel category either, because tax-refunded gallons are not included in the IFTA Net Taxable Gallons first term.
} 
-The IFTA and intrastate motor carrier taxable and tax paid gallons are entered on the 2nd page IMC adjustment of the FHWA551 and the net is included in the gross volume reported on page 1 .

- [Our State] participates in an IFTA regional processing center (RPC). Volumes for net taxable gallons are readily available for those returns processed by this RPC. For FHWA reporting purposes, net taxable gallons are captured directly from the Department's mainframe computer database.

For returns filed with [our State] by carriers whose base jurisdictions are outside of [our State's] RPC, IFTA volumes data are compiled using actual gallons provided on carriers' paper transmittals. After adjustments for amended entries, taxable gallons or liters and tax-paid gallons or liters are totaled for each fuel type for each transmittal. Canadian-based carrier data, provided in liters, is converted to gallons. Net IFTA gallons are calculated by subtracting the total tax-paid gallons from the total taxable gallons.

Net taxable gallons from each source are then combined for FHWA reporting.

IFTA tax revenues are captured from monthly financial reports of collections prepared by the Department's Accounting Bureau.

-For the monthly Motor Fuel Consumption Report 551M, [our State's] Department of Taxation provides a monthly report of volumes and revenues for gallons bought outside the state and used in the state as well as gallons and revenues bought in the state and used outside the state. The net calculation is simply the subtraction of one from the other. IFTA gallons bought in the state and used in the state are not a factor since these gallons are included in the state excise motor fuel tax number and therefore included in the gross gallons taxed.

-Net IFTA volumes consist of

(1) Net [IFTA gallons our State] received from [our State's] carriers PLUS

(2) Foreign Gallonage volumes received from jurisdictions on foreign based carriers MINUS

(3) Foreign Gallonage volumes sent to jurisdictions on foreign-based carriers.

-Total deposits - refunds to carriers - payments to other IFTA jurisdictions $=$ Net Receipts. Net Receipts / total tax rate $=$ volume (gallons).

The States' responses to question R1 show that a variety of approaches are being taken in calculating net IFTA gallons. At least three of the States are evidently using fuel volumes directly from IFTA reports for the 551M adjustment. According the Guide to Reporting Highway Statistics, though not the preferred method, net fuel consumption can also be calculated "by dividing the net dollars (less penalty and interest) by the tax rate of the State where the fuel was consumed." The straightforward nature of this latter approach makes it attractive, especially in view of the complexity of the IFTA adjustment. This is the approach taken, for example, by the State whose response to question R1 is the last in the above list, even though, that particular State reported in response to question $\mathrm{C} 2$ that they do carry gallons along in their IFTA data processing. Question C2 is discussed next. 
Which States carry gallons along in their IFTA data processing is the subject of survey question C2:

\section{C2. In your State's IFTA data processing, are just dollars, or are both volumes and dollars, carried along in the accounting?}

Figure 10 shows that nine States reported that they do not even carry gallons along:

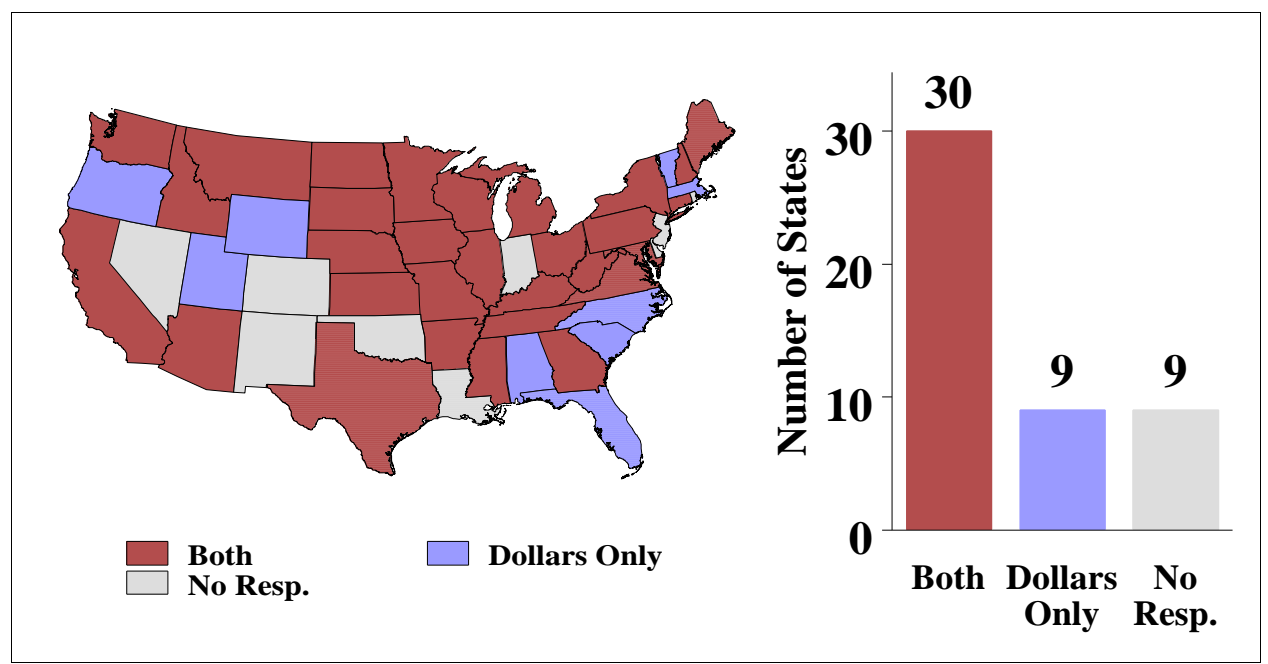

Figure 10. Responses to IFTA survey question C2 (see above).

Because IFTA reports are for calendar quarters and are issued two months after the end of each calendar quarter, IFTA adjustments used in Equation 1 do not necessarily correspond exactly to the fuel sales total for the month of the report. Question R4 on the survey was about the time delay in data processing:

\section{R4. What is the approximate or average time delay between when IFTA dollar or volume data is reported to your State by motor carriers and when your State reports the data for those same dollars or volumes to FHWA?}

Responses to question R4 are summarized in Figure 11. In cases where States gave a range of times (e.g., 1-3 months), the midpoints of the ranges were used to determine the State's category in the figure.

Another potentially confusing issue in Equation 1 is the term "IFTA" itself. The Guide to Reporting Highway Statistics (page 2-5) specifies that "the adjustment must reflect both motor fuel reported directly to the State and that reported through IFTA agreements." Nevertheless, because the 551M form (page 2) refers to these volumes collectively as "IFTA," it would seem an easy oversight to neglect in the 551M IFTA adjustment use-basis taxes collected for non-IFTA qualified vehicles or through special trip permits. 


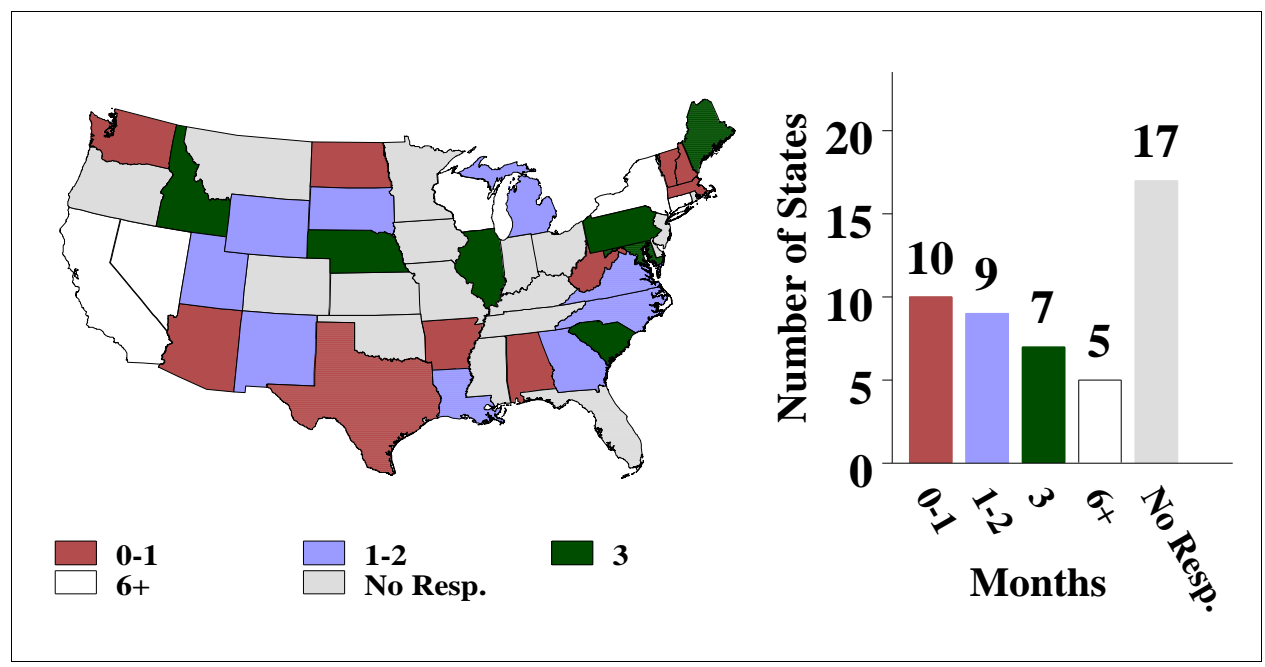

Figure 11. Responses to IFTA survey question R4 (see above). Midpoints of ranges were used for responses given as a ranges of months. The 0-1 category includes 1; the 1-2 category does not include 1; and all responses in the " 3 " category were exactly 3 . 


\section{Other Difficulties in Processing and Reporting IFTA Data}

Question R5 on the IFTA survey was about irregularities in data reported by the States to FHWA:

R5. Do you find any irregularities or inconsistencies from month to month, quarter to quarter, or year to year, in IFTA data your State reports to FHWA? If so please offer suggestions, comments, facts, opinions, etc.

Question R5 was similar to question C6 (see Figure 7), but R5 was about irregularities in data reported to FHWA, whereas C6 pertains specifically to irregularites in collections. Responses to questions R5 and C6 were nevertheless similar, suggesting that, as with collections, the IFTA reporting process is seen by the States as being reasonably regular. Responses to R5 are summarized in Figure 12.

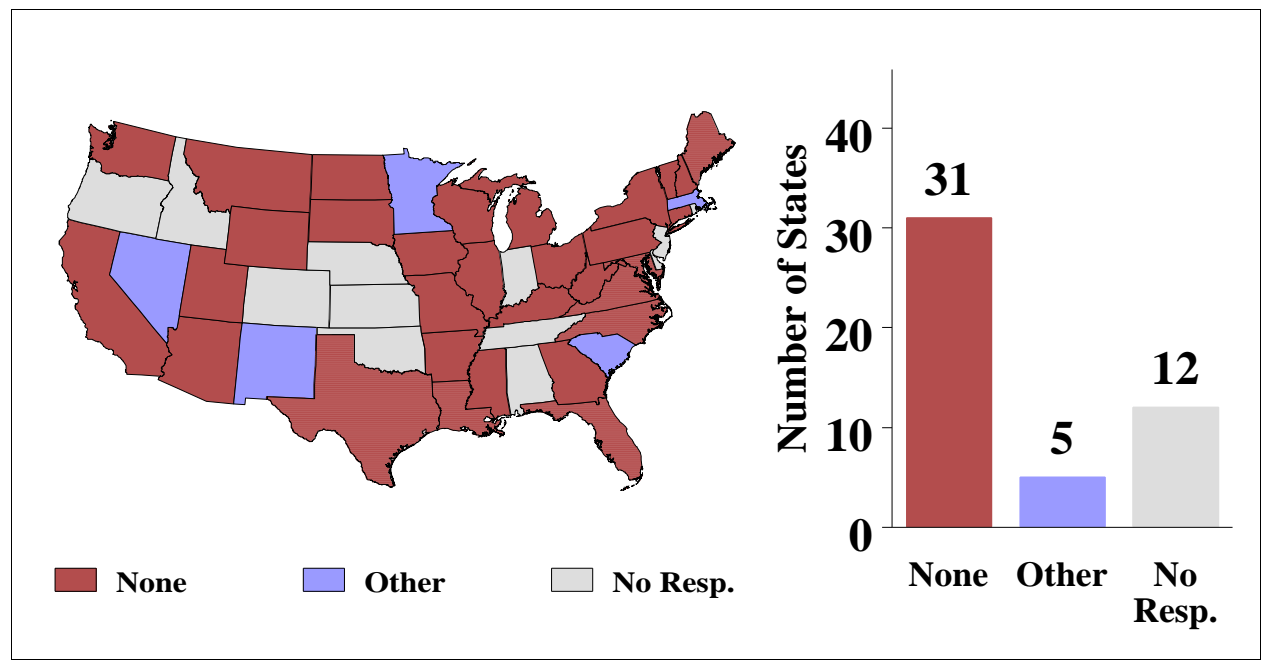

Figure 12. Responses to IFTA survey question R5 (see above).

Strictly seasonal effects and periodic behavior due to the IFTA quarterly reporting cycle were mentioned in several of the responses to question R5, but for Figure 12, those effects were considered as given, and those responses were included in the "None" category in the figure. Among the five responses in the "Other" category in Figure 12, were

-Yes, there are unexplained increases and decreases in the volumes reported. Month-to-month and quarter-to-quarter data are more irregular than the year-to-year data. The only check I have is to calculate fuel economy to see if it is close to our historical value of $5.7 \mathrm{mpg}$ for the average motor carrier. This lets me know if the miles reported and gallons used are reasonable.

Until every truck is tracked 24-7 with a GPS and the fuel economy is monitored, we will never know exactly when, where, and how much fuel is consumed on highways

-Yes, there does appear to be significant fluctuation in IFTA numbers, particularly since we have based FHWA reporting on net revenue amounts. For example, most monthly IFTA revenue amounts are positive, but occasionally we experience a month of net negative IFTA revenue. I have insufficient experience or expertise at this point to offer 
suggestions, comments or opinions.

-Yes, We have noticed that our gallons on the IFTA reports have been decreasing over the last year or so. With our traffic counts going up, this would make me believe that the motor carriers are manipulating the data for their benefit.

Except for this last remark, even the responses in the "Other" category do not seem to suggest serious irregularities in the data reported to FHWA. The last remark about carriers possibly misrepresenting their data because of State to State tax rate differences is addressed in Section 3 (see Figure 8 and surrounding discussion).

Two other questions posed on the collections part of the IFTA survey were directed at specific potential impediments to IFTA collections. ${ }^{12}$

\section{C11. Please describe any difficulties or other issues your State has in reporting tax data related to IFTA collections or reporting for fuel sold on Indian Reservations.}

\section{C12. For Texas, New Mexico, Arizona, and California only-what proportion of diesel fuel sold in your State would you estimate is consumed in Mexico (non-IFTA jurisdictions)?}

Responses to these questions also suggested few problems. Eight States did comment about fuel sold on Indian Reservations:

-The difficulty arises because tax is not collected on fuel being sold on the Indian Reservations. Fuel is often sold at a cheaper rate and truckers are unaware that tax is not included. The fuel purchase is often claimed on the IFTA tax return as tax paid fuel.

- [Our State] has several Indian Reservations within its borders. We are currently negotiating agreements with each tribe to provide data and revenues collected for sales to non-tribal members. The tribes would like to reduce the reporting burden they currently incur on behalf of the state.

—While there have been recent rumors of minor amounts of diesel being sold on Indian Reservations without imposition of state tax, I cannot verify the validity of the rumors or quantify any amounts. Presumably that fuel would be reported as a [purchase in our State] and a credit would be allowed the taxpayer (trucker) in the IFTA system, however, the state would have no corresponding revenue. Since we report to FHWA based on net revenue, we would be unable to report such Indian Reservation sales to FHWA.

Under [our State's] law, the sale of untaxed diesel on an Indian Reservation could only occur if a refinery or rack operator delivers the fuel to the Reservation (title to the fuel passes while within the Reservation), or if the fuel is imported into the state while within Indian Reservation boundaries. In those cases, the federal preemption against taxing an Indian doing business within his own Reservation would apply.

\footnotetext{
${ }^{12}$ Collection questions $\mathrm{C} 11$ and $\mathrm{C} 12$ were also posed as questions R7 and R8 on the FHWA reporting part of the survey. Here, responses to $\mathrm{C} 11$ and $\mathrm{R} 7$ or $\mathrm{C} 12$ and $\mathrm{R} 8$ are considered together.
} 
-None at this time. The carriers receive full tax paid credit for purchases made on reservations. The difficulty with reservation exemptions is that most carriers don't realize that a purchase is made on a reservation.

-We have three stations on [-] County, which sell tax-free fuel. We caught one carrier claiming tax-paid credit on fuel purchased ex-tax.

Other difficulties mentioned for reporting fuel sold on Indian Reservations were minor. Figure 13 summarizes all of the States responses to question C11:

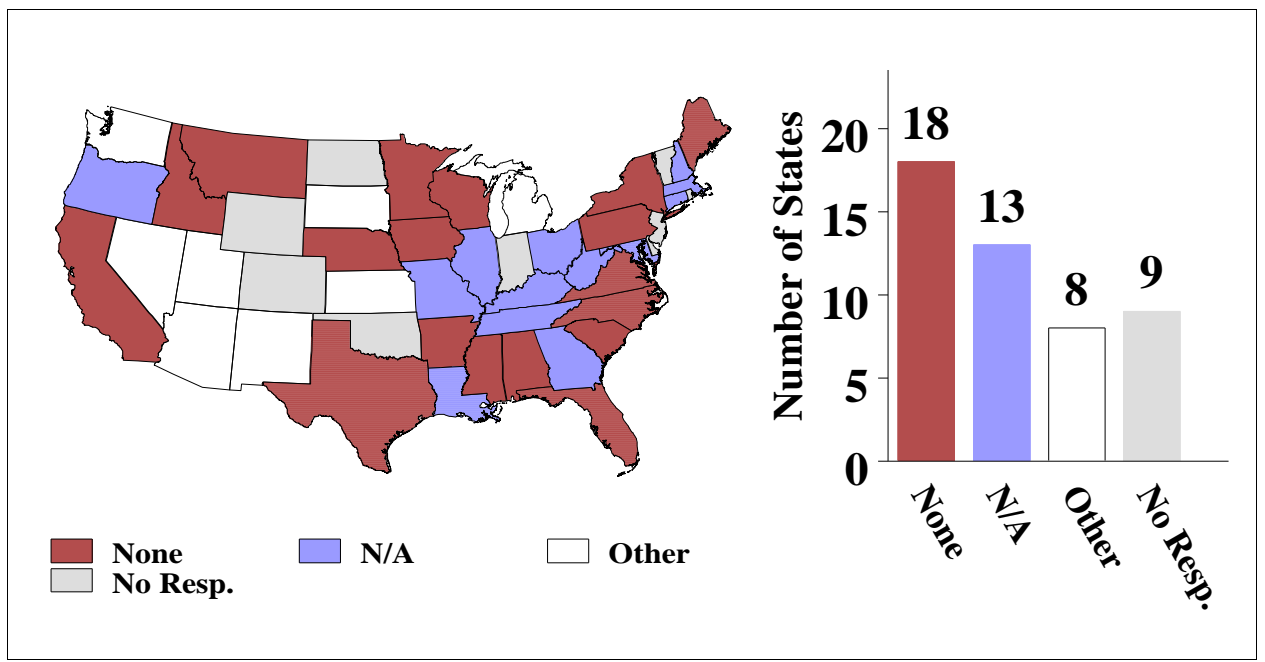

Figure 13. Responses to IFTA survey question C11 (see above).

Only States bordering Mexico were asked to respond to Question C12 about fuel consumed in Mexico. Although one of these States indicated they do not know the answer to C12, the responses of the three others States bordering Mexico all suggest that problems with fuel sold in these jurisdictions and consumed in Mexico are small, because there is very little fuel sold and used this way. Comments from the three States were essentially the same: Only an insignificant, fraction of a percent of fuel is sold and consumed this way.

For both the collections and reporting parts of the survey, a final question was posed as a catchall to pick up ideas not mentioned in previous responses:

C13. What obstacles or difficulties (other than any described above) do you encounter in IFTA collections? Other comments, suggestions, concerns, etc. about IFTA collections?

R9. What obstacles or difficulties (other than any described above) do you encounter in reporting IFTA data to FHWA? Other comments, suggestions, concerns, etc. about data reported to FHWA by your State?

When they got to either of questions C13 or R9, most States (29 for C13 and 35 for R9) did not list further problems with the IFTA collections and reporting systems. Many of the remarks from those State's that did comment were about day-to-day business problems that, though important, only indirectly affect the data reported to FHWA. These problems include carriers going out of business or changing their identification, auditing issues, unlicensed carriers, roadside 
enforcement, staffing shortages, fees transmitted without complete accounting information, information processing and electronic business issues, and delinquency in filing and payment.

Rather than mentioning obstacles or difficulties, several respondents to question C13 instead praised IFTA. For example, one State's response to C13 was "None, IFTA works very well as a base-state reporting system." Another State's response was "We have had complete cooperation from other jurisdictions."

One State responded to question $\mathrm{R} 9$ by reiterating the problem of gallons not being separated out in reports from their department of revenue. Several other responses to question R9 pertained directly to FHWA reporting:

-We have been unable check to see if the amendments to our 551M and 556 forms have been successfully received by FHWA and getting input into the database. The new Smart Tool, web based data entry device, appears to give real-time feedback. [Our State] DOT looks forward to the new reporting tool and working with our FHWA Regional Office to improve our reporting techniques.

- The unit charged with reporting IFTA data to FHWA is separate from the IFTA Processing Unit. The reporting of IFTA statistics follows what was already established in previous practices. Efforts should be made to gain better understanding of information between the two units to evaluate the relevance of IFTA data.

-IFTA reporting if fraught with inaccuracies because of the nature of the reporting. We are at the mercy of the trucker's data that is provided, if it has inaccuracies then obviously what we pass on to the FHWA does as well.

In this last example response listed above, the second sentence is clearly true: the IFTA reporting system does depend on the accuracy of the trucker's reported data. However, because of IFTA's stringent auditing requirements and the threat of IFTA license revocation, most States did not seem to agree with the first sentence of that State's response, that IFTA data is fraught with inaccuracies. 


\section{Timeliness}

Delay is a potential problem in any data acquisition effort. In the reporting of fuel volumes by the States to FHWA, the delay is the time from when fuel is consumed to when FHWA receives a report about that fuel's consumption. The calendar quarter system, which all IFTA member States follow, tends to delay the monthly system of FHWA 551M reports. According to the Guide to Reporting Highway Statistics, IFTA fuel volumes may be reported to FHWA according to when tax payments for those volumes are received, even when fuel volumes for which those taxes are due were determined by audit or reported without payment. Potentially, then, late tax payments could induce reporting delays.

Nevertheless, for several reasons, timeliness does not appear to be a serious difficulty in the IFTA data reports States submit to the FHWA. For the most part, FHWA only needs to estimate relative consumption. To the extent that proportions of late payments do not vary from State to State, relative consumption estimates are unaffected by reporting delays. Furthermore, as responses to the survey question C6 (discussed in Section 2) indicate, IFTA operations are fairly regular. This suggests that effects of late payments in IFTA reporting tend to cancel during each period, with late payments from previous periods compensating for late payments to be counted later. As responses to survey question C8 (also in Section 2) indicate, yet another reason that timeliness does not appear to be a serious difficulty is that the rate of IFTA late payments is itself generally low.

If we assume that fuel consumption is approximately uniform over calendar quarters and that motor carriers report at the very end of the month following the calendar quarter they are reporting for, then the average delay between fuel consumption and when States are notified about that consumption is $3 / 2+1=2.5$ months for carriers operating in their base jurisdictions, and $3 / 2+2=3.5$ months for carriers operating outside their base jurisdictions. Responses to Question R4 suggest that the average time delay between when motor carriers report to the States and when the corresponding volumes are reported to FHWA is 2.7 months. Thus, according to these approximations, the total delay between when fuel is consumed and when FHWA is notified of the consumption is, on average, about 5.3 months for mileages by carriers operating within their base jurisdictions and about 6.2 months for mileages by carriers operating outside their base jurisdictions. This is consistent with the approximate flow chart schedule in Figure 3.

The estimates of 5.3 and 6.2 months delay ignore additional delays for late payments and audits and assessments. Survey question C9 applies to late filing and assessments. The purpose of question C9 was to determine if late payments were having a significant impact on timeliness of data reported to FHWA:

\section{C9. What is the average lag time between when assessment collections are actually made and when the assessed taxes should have been reported?}

Responses to this question were varied. Several of the responses referred explicitly or implicitly to IFTA "Option 2" filing. IFTA "Option 2" filing is defined in the IFTA Procedures Manual as "When a licensee files a return and fails to remit full payment with his return, full payment of the reported tax and interest, if any, will be made by the base jurisdiction to the member jurisdictions involved. The base jurisdiction will assume the liabilities for the payments made to the other jurisdictions." Thus: 
-We do not have this data. [Our State] submits the tax to other jurisdictions even if the tax was not collected. We use option \# 2 under P1060.200 as do most jurisdictions.

- Since [our State] pays a carrier's complete liability to all jurisdictions as soon as a return is posted, the internal processes at this department for collection of liabilities should not be of interest to anyone outside of [our State].

States being notified of volumes consumed in Option 2 jurisdictions, receive the tax revenue for that consumption at the same time. Thus volumes reported by motor carriers from "Option 2" States for operations outside their base jurisdictions should be reported to FHWA on time, even when the tax payments for those volumes are late.

Some States, in their responses to question C9, gave estimates of reporting time delays and the extent of late payments.

-30-60 days. [Our State] revokes its IFTA licensees if returns aren't filed timely and the proper amount of fuel use tax isn't paid to [our State] as well as the other states, so [our State] has excellent compliance from its IFTA licensees.

-In virtually all cases we will send the money \& transmittal for reports received in a particular month, by the end of the next month. Most Jurisdictions will also follow this policy, unless the report had errors that required addition work before exact amounts could be tabulated for transmission. In the case of audits or amended returns, the time lag can range from a month to several years depending on the payment and appeal status of the carrier.

-[Our State] has about 2500 IFTA accounts. For any given quarter, about 250-300 are delinquent filers. Most of these clear within a year. The annual license renewal process forces many to file their delinquent returns.

- [Our State] has estimated that $91 \%$ of its carriers file timely and the remaining $9 \%$ (per quarter) would fall into the "lag time" category that could vary from one month to twelve months. [Our State] has many carriers that file all four quarterly returns during its annual IRP renewal cycle. However, [our State] is an option 2 jurisdiction, which means full payment is made by [our State] to the affected member jurisdictions upon receipt of payment. [Our State] is thereby responsible for its own collection of unpaid tax, interest and penalty.

-Assessments based on audits are generally collected within 2 months following the initial audit assessment. Most returns are filed and paid timely. On average, we have approximately $3 \%$ delinquencies per quarter.

Because audits and late payment collections are for the most part an ongoing and continuous process, these responses suggest that reported volumes should not be affected much by late payments, and even if late payment totals did vary a lot (i.e., were an irregular and discontinuous process), the IFTA "option 2" still reduces the extent of late data reporting to FHWA.

Thus various conditions tend to minimize the effect on apportionments of IFTA data reporting delays. To reiterate, 
- Relative consumption estimates only affect late payments to the extent that the proportions of late payments differ from State to State

- The rate of late payments is relatively constant from year to year, so that effects of late payments tend to cancel

- Rates of late payments are fairly low

- Delays are not excessive

- The payments that IFTA "option 2" States make to other States for fuel consumption motor carriers report to them are timely, even if the tax payments from the motor carriers are late.

Though they are mitigating, however, these conditions do not preclude problems with data timeliness. And, as discussed in the next section of this report, interim estimates of IFTA corrections should be reasonably straightforward to compute, should IFTA data be late. 


\section{Alternatives for IFTA Calculations if the Complete IFTA Data Are Not Available}

The third reporting question (R3) on the IFTA survey was

R3. Does your State use IFTA data to calculate entries for FHWA form 551M, Item 1, Gross-Volume Reported? Does your State use IFTA data to compute entries for page 1 of FHWA form 556 (for example lines 1-4 of section 1.a)? If the answer to either of these questions is no, or if the complete IFTA data for a reporting period is unavailable, what data is used instead?

Responses to this question indicate that most of the States do use IFTA data to complete the FHWA forms, both 551M and 556. Figure 14a summarizes results for whether IFTA data is used for $551 \mathrm{M}$ forms, and Figure $14 \mathrm{~b}$ summarizes results for whether IFTA data is used for the 556 forms.

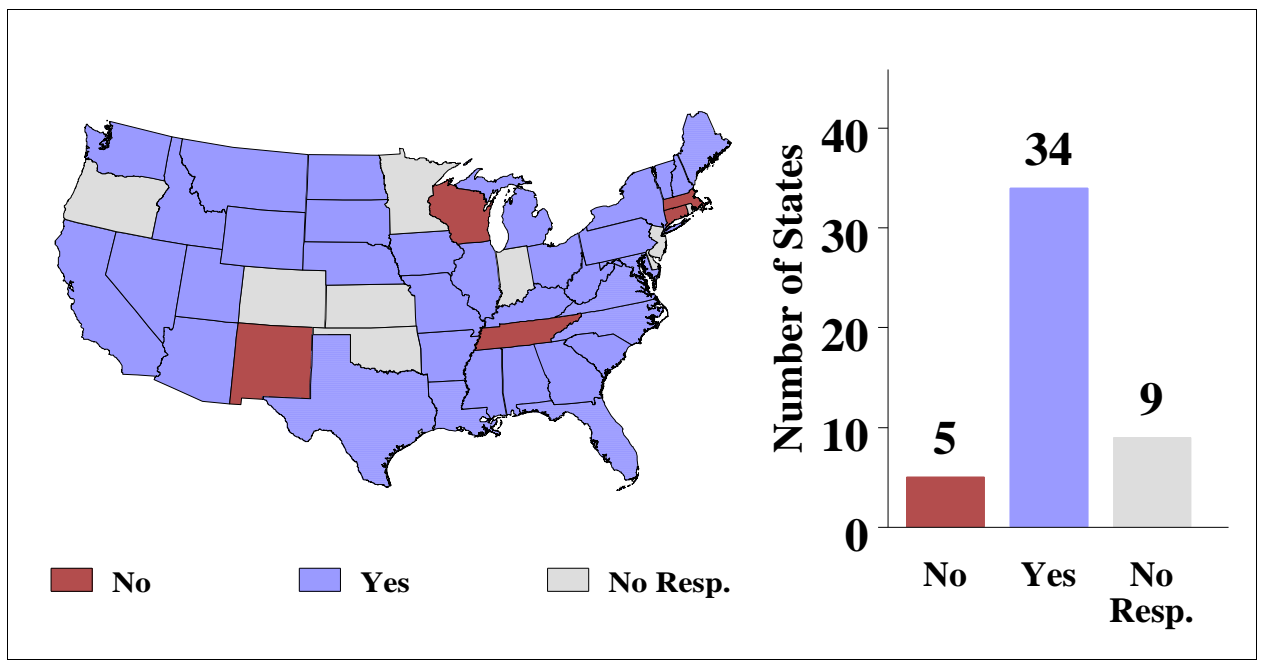

Figure 14a. Responses to whether IFTA data is used for the $551 \mathrm{M}$ forms (the first part of IFTA survey question R3).

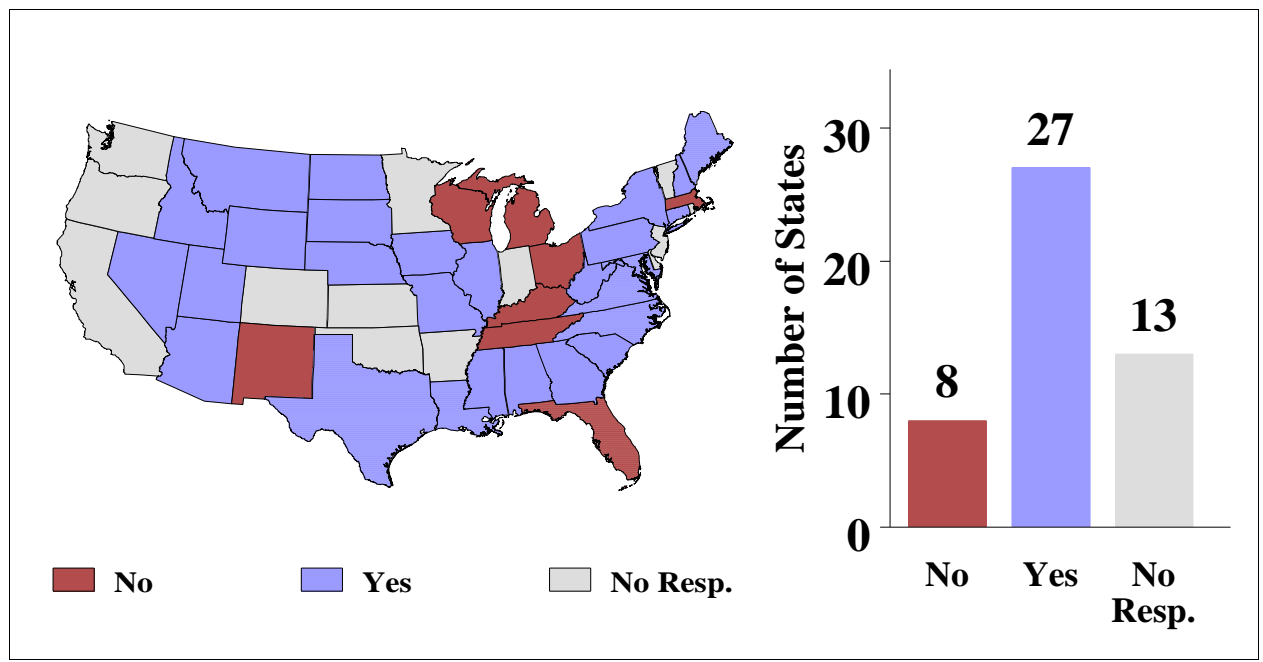

Figure 14b. Responses to whether IFTA data is used for the 556 forms (the second part of IFTA survey question R3). 
Several respondents explained what they did instead of using IFTA data on forms $551 \mathrm{M}$ or 556. For example

- [Our State] does not use IFTA data to calculate entries for FHWA Form 551M, Item 1, Gross Volume Reported. Neither does [our State] use IFTA data to compute entries for page 1 of FHWA Form 556. In both cases, page 1 information is derived from monthly gasoline and special fuels reports. Information relating to the balance of IFTA payments [our State] receives from other states is entered on page 2 of both FHWA Form 551M and FHWA Form 556.

-No. [Our State's] Department of Revenue (DOR) calculates total gallons reported on the monthly 551M, line 1 from fuel tax revenues DOR collects. While these revenues include fuel tax revenues from Interstate Motor Carriers, IFTA data collected by [our State's] Department of Transportation (DOT) is not received or known until much later. For FHWA-556 line 1.a. (1): No. Gross collection data is taken from the monthly 551M's prepared by DOR. On line 1.a. (4), IFTA refunds and credits, as calculated at DOT, are added to other fuel tax refunds and credits reported by DOR.

No one, however, offered explicit suggestions about what to do if IFTA data is late or unavailable. Perhaps this is because the survey respondents did not view timeliness as a serious problem in IFTA collections.

Nevertheless, reporting delay might still be a problem from FHWA's perspective, and with most of the forty eight IFTA-member States submitting monthly 551M reports on time, there is likely to be a basis for computing reasonably good proxy estimates of data from IFTA reports, if that data is occasionally unavailable for a few States. Interim estimates would be useful, because they would allow other totals (e.g., national totals) to be computed and examined for tentative calculations and planning. They could be used in spreadsheets, for example, where they could be easily replaced with actual data when it becomes available.

Interim estimates for late fuel consumption data could be based on any or all of the following:

- Time series of previous values of the data element whose current value is late

- On-time and previous values of the data element for geographically similar States

- Other data sources such as vehicle registrations, vehicle mileage estimates, the IRS's ExSTARS (Excise Summary Terminal Activity Reporting System), and fuel producer data

For example, suppose that on the FHWA form 556 for 2002, the entry for "Net IMC Fuel Tax Receipts" is missing for State X, but that entry is available for 2001 for State X, and that entry is available for 2002 for States Y and Z, which are both nearby X and similar to X in industry, agriculture, population density, etc. Also suppose that vehicle registration data for 2002 for all States is available. Then it seems reasonable to base an interim estimate of the 2002 "Net IMC Fuel Tax Receipts" for State X on the 2001 data for X, the 2002 data for States Y and Z, and the vehicle registrations.

Interim estimation procedures could be derived using time series and regression analysis applied to historic data. (This approach would have to demonstrate a correlation between actual data 
elements and estimates of them.) Use of data from nearby and similar States and other on-time data would help to account for growth and economic and other cyclical trends in the data elements to be estimated. Because the estimates would be based on previous data for the same State as well as on-time data from similar States and other on-time data, long time series of previous values of the element to be estimated would not be needed-only the last one or two reported values would be necessary. Therefore, such an approach could be used even with IFTA data, which many States have collected only for the past few years. 


\section{Conclusions}

The responses of the States suggest that IFTA collections and data reporting processes are for the most part working well. Possible exceptions include (1) using off-road fuel use in IFTA mpg estimates, (2) inconsistencies among States in definitions of taxable mileage pr taxable fuel and consequential reporting differences, and (3) possible misinterpretations of "net taxable gallons."

The problem with using off-road fuel use in IFTA mpg estimates is that it tends to inflate taxable gallon estimates, because off-road per-gallon mileage is generally lower than on-road mileage. The problem with inconsistent definitions of taxable mileage or fuel is that IFTA taxable gallons for one State can include fuel that if used in another State would not be included. In Idaho, for example, fuel usage on privately maintained roads on private property is not taxable; in Connecticut all miles are taxable.

The problem with the interpretation of "net taxable gallons" is that in the language of FHWA (as on the 551 forms) "net taxable gallons" refers to the difference between taxable gallons used and taxable gallons purchased. In the language of IFTA, on the other hand, "net taxable gallons" refers to a balance of gallons on which taxes are due. The consequence is that the IFTA net taxable gallons differ from the IFTA adjustment FHWA ask for on the 551M forms. The difference is equal to the volume purchased tax-refunded less the volume purchased tax-due.

There is no accounting or auditing evidence that motor carriers may be misreporting mileages to take advantage of State-to-State differences in fuel tax rates. Nevertheless, some of the State personnel who were surveyed indicated they believe this to be the case. Mileages that are misreported to take advantage of differential fuel tax rates would tend to incorrectly reduce IFTA mileages and volumes for States with higher fuel rates.

Several other possible exceptions to the smooth operation of IFTA collections and data reporting include mileage deductions for travel on the Massachusetts turnpike; possible misinterpretations of what is considered "IFTA" on 551M reports; the dependency of the entire system on the accuracy of trucker reports; exemptions, in certain States, for IFTA-qualified buses or two-axle trucks; and commingling, in the accounting, of direct fuel tax revenue with revenue (e.g., penalties and interest) not directly proportional to volumes consumed.

Responses to the IFTA survey suggest that delay is not a serious problem in IFTA data reporting to FHWA. Nevertheless, delay might be a problem from FHWA's perspective. Furthermore reporting delays (if encountered) might be remedied fairly easily with interim estimates computed from such data sources as time series of past data and on-time data from States that are similar to the State whose data in delayed.

Although the IFTA collection and FHWA reporting systems are not perfect, the general tone of the responses to the survey is positive. IFTA is a vast improvement over earlier fuel tax collection systems in which motor carriers had to report separately to each jurisdiction they operated in. In general the survey respondents indicated that the IFTA system is working well. 


\section{References}

[1] Public Law 105-178-June 9, 1998, 105th Congress, http://www.bts.gov/lawlib/docs/p1105_178.pdf.

[2] Attribution and Apportionment of Federal Highway Tax Revenues: Process Refinements, Office of Highway Policy Information, Federal Highway Administration, February 2002, http://www-cta.ornl.gov/Publications/FuelTaxProcess/index.html.

[3] "HIGHWAY FUNDING: Problems With Highway Trust Fund Information Can Affect State Highway Funds," U.S. General Accounting Office, GAO/RCED/AIMD-00-148, June 2000 .

[4] Federal Register, Vol. 65, No., 160., August 17, 2000, 50269-50272. (To retrieve this Notice use the search tool at http://www.access.gpo.gov/su_docs/aces/aces140.html. To retrieve the comments about the Notice, see http://dms.dot.gov/search/ and search for the"7635" (end of docket number)).

[5] The IFTA News, 23, December 1996, http://www.iftach.org/Newsltr/1296.htm.

[6] International Fuel Tax Agreement Articles of Agreement, January 1996, http://www.iftach.org/revision2002/AA.pdf.

[7] International Fuel Tax Agreement: A guide for Utah motor carriers, http://www.tax.ex.state.ut.us/CurrentPackX/Publications/Pub-15/iftaman.htm.

[8] International Fuel Tax Agreement Procedures Manual, January 1996, http://www.iftach.org/revision2001/nov/pm.pdf.

[9] A Guide to Reporting Highway Statistics, FHWA, Office of Highway Policy Information, http://www.fhwa.dot.gov/ohim/ghwystat.htm.

[10] International Fuel Tax Agreement Audit Manual, January 1996, http://www.iftach.org/revision2002/AM.pdf.

[11] http://www.state.ma.us/legis/laws/mgl/64A-7.htm.

[12] http://www.massdor.com/publ/pdfs/tpk_rfd.pdf.

[13] "General Instructions for Idaho Form 75-IMV,"

http://www2.state.id.us/tax/pdf/2001/2001\%20Forms/01F75IMV.pdf.

[14] "International Fuel Tax Agreement Information," State of Connecticut. Department of Revenue Services, http://www.drs.state.ct.us/formlib/2001/Pubs/IP/IP01-32.pdf. 


\section{Appendix A. IFTA Survey (January 2002) Questionnaire}

(Please fill out the following identification fields.)

Name:

Title:

Functional organization:

Address:

Email:

Phone:

\section{IFTA Collections Questions}

C1. What obstacles (if any) does your State encounter in following the IFTA Procedures Manual (http://www.iftach.org/recod/pm.pdf) or the IFTA process in general?

C2. In your State's IFTA data processing, are just dollars, or are both volumes and dollars, carried along in the accounting?

C3. Please describe any special circumstances that make IFTA reporting for your State different from or more difficult than for other States.

C4. What departures, if any, does your State usually take from the IFTA Procedures Manual or from what you understand to be IFTA procedures typical for other States?

C5. Are calendar quarters the IFTA reporting periods for motor carriers from your State? If not what are the reporting periods? What is the time (e.g., one month) from the end of the reporting period to the due date for the motor carrier returns?

C6. Do you find any irregularities or inconsistencies from month to month, quarter to quarter, or year to year, in IFTA revenue collections? If so please offer suggestions, comments, facts, opinions, etc.

C7. Do checks sent from your State to other States include payments not directly proportional to volumes consumed (for example, for penalties, interest, or refunds for overpayments)?

C8. Are IFTA payments to and from your State generally on time? If not, please offer suggestions, comments, facts, your own opinions, etc.

C9. What is the average lag time between when assessment collections are actually made and when the assessed taxes should have been reported?

C10. Do you think that motor carriers are claiming higher mileages in States with low fuel tax 
rates than they would if State fuel tax rates were uniform?

C11. Please describe any difficulties or other issues your State has in reporting tax data related to IFTA collections or reporting for fuel sold on Indian Reservations.

C12. For Texas, New Mexico, Arizona, and California only-what proportion of diesel fuel sold in your State would you estimate is consumed in Mexico (non-IFTA jurisdictions)?

C13. What obstacles or difficulties (other than any described above) do you encounter in IFTA collections? Other comments, suggestions, concerns, etc. about IFTA collections?

C14. If your State has a procedures manual or other documents (specific to your State) on IFTA collections and data processing, please provide a copy to ORNL using the return email, mail, or fax addresses listed in the instructions.

\section{FHWA Reporting Questions}

R1. Please describe how your State calculates net IFTA volumes and revenues.

R2. If applicable, please describe how your State separates out IFTA revenues not directly proportional to volumes of motor-fuel (penalties, interest, decal fees, refunds for overpayments, etc.) from direct IFTA motor-fuel gallon taxes?

R3. Does your State use IFTA data to calculate entries for FHWA form 551M, Item 1, GrossVolume Reported? Does your State use IFTA data to compute entries for page 1 of FHWA form 556 (for example lines 1-4 of section 1.a)? If the answer to either of these questions is no, or if the complete IFTA data for a reporting period is unavailable, what data is used instead?

R4. What is the approximate or average time delay between when IFTA dollar or volume data is reported to your State by motor carriers and when your State reports the data for those same dollars or volumes to FHWA?

R5. Do you find any irregularities or inconsistencies from month to month, quarter to quarter, or year to year, in IFTA data your State reports to FHWA? If so please offer suggestions, comments, facts, opinions, etc.

\section{Please note: If you have already answered questions $\mathrm{C10}, \mathrm{C11}$, and $\mathrm{C12}$, then skip to question R9.}

R6. (Skip this question if you already answered question C10). Do you think that motor carriers are claiming higher mileages in States with low fuel tax rates than they would if State fuel tax rates were uniform?

R7. (Skip this question if you already answered question C11). Please describe any difficulties or other issues your State has in reporting tax data related to IFTA collections or reporting for fuel sold on Indian Reservations.

R8. (Skip this question if you already answered question C12). For Texas, New Mexico, 
Arizona, and California only-what proportion of diesel fuel sold in your State would you estimate is consumed in Mexico (non-IFTA jurisdictions)?

R9. What obstacles or difficulties (other than any described above) do you encounter in reporting IFTA data to FHWA? Other comments, suggestions, concerns, etc. about data reported to FHWA by your State?

R10. If your State has a procedures manual or other documents (specific to your State) on how to handle IFTA data reporting to FHWA, please provide a copy to ORNL using the return email, mail, or fax addresses listed in the instructions. 


\section{Appendix B. IFTA Survey (January 2002) Instructions for Questionnaire}

The current Federal and State systems of fuel tax administration are the products of a long evolution. Today, all States report motor-fuel consumption and tax revenue data to the U.S. Federal Highway Administration (FHWA). That data is used, along with statutory formulas, to decide how Federal fuel tax revenues are apportioned to the States for use in various highway programs. Because the amount of Federal fuel tax revenue apportioned this way is huge (around 12 billion dollars), it is in everyone's interest that the data the States report to FHWA should be as accurate as possible. FHWA would like to improve and standardize its processing of the fuel tax and consumption data reported by the States, and to improve its instructions to the States. IFTA data is an area where FHWA would particularly like to improve its reporting instructions.

Please fill out the attached survey questionnaire about how your State processes IFTA data and how it reports that data to FHWA. The questionnaire is being sent to all forty eight IFTA member States (all States except Alaska and Hawaii). The purpose of the survey is to ensure that FHWA properly understands the States' IFTA data collection processes and obstacles the States may be encountering in timely and accurate reporting of IFTA data. The purpose is in no way an attempt to monitor or change the IFTA revenue collection process of any State.

FHWA would like your insights, advice, suggestions, or concerns about the IFTA motor fuel tax collection and reporting process. To focus on information that will be most useful to FHWA, please keep in mind the following four-part principle: for every gallon of fuel consumed in the nation, what FHWA ultimately tries to determine from the State data is (1) the type of the fuel (gas, diesel, etc), (2) the State the fuel was consumed in, (3) whether the fuel was consumed onhighway or off-highway, and (4) when the fuel was consumed. Thus FHWA would be interested, for example, in difficulties you may have in dealing with late, incomplete, or inaccurate data, but would not be interested in, say, the accounting software used to compute IFTA totals. Keeping the four-part principle in mind will help you focus on what FHWA would most like to know.

In most States, different agencies perform different roles in the overall IFTA collections and data reporting process. Therefore, you may not be familiar with some of the procedures considered in the questionnaire. You should answer the questions you are knowledgeable about, but you need not answer all the questions. To simplify the survey, the questionnaire has been divided into separate sections for IFTA collections and for FHWA reporting. Only complete both sections if you are familiar with both IFTA collections and FHWA reporting. If you do complete both sections, then please skip questions R6, R7, and R8, which are the same as questions $\mathrm{C} 10, \mathrm{C} 11$, and $\mathrm{C} 12$.

Please be as specific as possible in answering the survey questions. For example, refer as needed to particular documents, forms, instructions, or lines, whether from FHWA, IFTA, Inc., or your own State. Please include copies of your own State's IFTA procedures documentation when you return your questionnaire (see questions C14 and R10). FHWA forms 551M (Monthly MotorFuel Consumption) and 556 (State Motor-Fuel Tax Receipts and Initial Distribution by Collection Agencies) are available at http://www.fhwa.dot.gov/ohim/formlist.html.

A one-page document "IFTA Fuel Consumption Reporting to FHWA by the States" and an accompanying flow chart are included with these instructions. ${ }^{13}$ They describe FHWA's current understanding of IFTA fuel consumption reporting, and are intended to serve as references to

\footnotetext{
${ }^{13}$ This document and flow chart have been incorporated into the IFTA background discussion in Section 2 of this report and are not included here.
} 
facilitate answering the questionnaire.

This survey is being administered for FHWA by the Oak Ridge National Laboratory (ORNL). Please use an electronic (Word or WordPerfect) version of the questionnaire, and return the completed questionnaire by email attachment to ric@ornl.gov. If you cannot use an electronic version, fill out a hard copy and either fax the completed questionnaire to 865-574-3851 or mail it to

Dr. Rick Schmoyer

Center for Transportation Analysis

Oak Ridge National Laboratory

Oak Ridge, Tennessee 37831-6073

If you have any questions about the survey, please contact Rick Schmoyer (865-574-1044) or Bob Boundy (865-576-7827). Thank you for taking the survey. Your answers will be most appreciated 


\section{DISTRIBUTION}

1. Ralph Erickson, FHWA

2. Tom Howard, FHWA

3. Pat $\mathrm{Hu}$

4. Ted Fox

5. Carolyn Moser 